OPEN ACCESS

Edited by:

Fabrice Martin-Laurent, Institut National de la Recherche

Agronomique, France

Reviewed by:

Stephanie A. Smith,

Washington State University, USA

Edoardo Puglisi,

Università Cattolica del Sacro Cuore,

Italy

${ }^{*}$ Correspondence:

Mariusz Cycon

mcycon@sum.edu.pl

Specialty section: This article was submitted to

Systems Microbiology,

a section of the journal

Frontiers in Microbiology

Received: 25 April 2016 Accepted: 15 June 2016

Published: 28 June 2016

Citation:

Cycoń M, Borymski S, Orlewska K, Wąsik TJ and Piotrowska-Seget Z (2016) An Analysis of the Effects of

Vancomycin and/or Vancomycin-Resistant Citrobacter freundii Exposure on the Microbial

Community Structure in Soil.

Front. Microbiol. 7:1015

doi: 10.3389/fmicb.2016.01015

\section{An Analysis of the Effects of Vancomycin and/or Vancomycin-Resistant Citrobacter freundii Exposure on the Microbial Community Structure in Soil}

\author{
Mariusz Cycon ${ }^{1 *}$, Sławomir Borymski ${ }^{2}$, Kamila Orlewska ${ }^{1}$, Tomasz J. Wąsik ${ }^{1}$ and \\ Zofia Piotrowska-Seget ${ }^{2}$
}

1 Department of Microbiology and Virology, School of Pharmacy with the Division of Laboratory Medicine, Medical University of Silesia, Sosnowiec, Poland, ${ }^{2}$ Department of Microbiology, University of Silesia, Katowice, Poland

The occurrence of antibiotics and antibiotic resistance genes in the environment has become a subject of growing concern. The extensive use of vancomycin and other pharmaceuticals may alter the biodiversity of soil microbial communities and select antibiotic-resistant bacteria. Therefore, the purpose of the study was to evaluate the impact of vancomycin and/or vancomycin-resistant Citrobacter freundii on soil microbial communities using the denaturing gradient gel electrophoresis (DGGE) and the phospholipid fatty acid (PLFA) approaches. The experiment had a completely randomized block design with the following treatments: control soil (C), soil with vancomycin (1 mg/kg soil-VA1), soil with vancomycin (10 mg/kg soil-VA10), soil with $C$. freundii (Cit), soil with vancomycin (1 mg/kg soil) and C. freundii (VA1+Cit), and soil with vancomycin (10 mg/kg soil) and C. freundii (VA10+Cit). A bacterial strain resistant to vancomycin was isolated from raw sewage collected from the municipal sewage treatment plant. The obtained results indicated that the antibiotic and/or the bacterial strain exerted a selective pressure that resulted in qualitative and quantitative changes in the population of soil microorganisms. However, a multivariate analysis showed that the genetic and structural diversity of the soil microbial community was primarily affected by the incubation time and to a lesser extent by the antibiotic and introduced bacteria. DGGE analysis clearly showed that certain species within the bacterial community were sensitive to vancomycin as was evidenced by a decrease in the values of $S$ (richness) and $H$ (Shannon-Wiener) indices. Moreover, a PLFA method-based analysis revealed alterations in the structure of the soil microbial community as indicated by changes in the biomass of the PLFA biomarkers specific for Gram-positive and Gram-negative bacteria as well as fungi. The changes observed in the community of soil microorganisms may decrease the rate of microbial-mediated processes, which can lead to a disturbance in the ecological balance of the soil ecosystem.

Keywords: vancomycin, antibiotic resistance, Citrobacter freundii, DGGE, PLFA, soil 


\section{INTRODUCTION}

The intensive use of antibiotics, their disposal and consequent presence in water and soils are of great concern regarding their ecotoxicological effect on the organisms of different trophic levels and the spreading of antibiotic resistance genes (ARGs; Kümmerer, 2009). Antibiotics are commonly used in human and veterinary medicine, livestock industries and agriculture. Such widespread use results in an increased concentration of antibiotics in water, sediments, and soils. Antibiotics enter the environment in various ways. The primary sources of pharmaceutical contamination include domestic, industrial, and hospital wastewater, as well as effluents from wastewater treatment plants (WWTPs), aquaculture and livestock farming (Bottoni et al., 2010). Since conventional WWTPs have a limited efficiency in removing antibiotics from wastewater, these chemicals are released into water bodies and soils (Li and Zhang, 2010). Moreover, the application of manure and sewage sludge as fertilizers can contribute to the spread of pharmaceuticals and antibiotic-resistant microorganisms into soil (Kümmerer, 2003; Bondarczuk et al., 2016). For example, Su et al. (2015) found 156 ARGs encoding resistance to various antibiotics in composted sewage sludge showing that this by-product is a reservoir of antibiotic-resistance determinants.

The amount of antibiotics in water ranges from nanograms per liter in surface water to micrograms and milligrams per liter in effluents from hospital, an antibiotic drug manufacturers and WWTPs (Brown et al., 2006; Larsson et al., 2007; Tamtam et al., 2011). The results of many studies have provided evidence of the presence of many antibiotics in the soil at concentrations ranging from $\mathrm{ng} / \mathrm{kg}$ soil to hundreds of $\mu \mathrm{g} / \mathrm{kg}$ soil (Aust et al., 2008; Karci and Balcioglu, 2009). Although the concentration of environmental antibiotics is not high, recent studies have shown that even low concentrations of antimicrobials select antibiotic-resistant bacteria, maintain the ARGs and favor horizontal gene transfer (Kim et al., 2003; Gullberg et al., 2011, 2014). Xiong et al. (2015) observed that the tetracycline present in manure polluted freshwatersediment was important for maintenance of tet genes encoding resistance of bacteria to tetracycline. Apart from the emergence of antibiotic-resistant bacteria, antibiotics present in soil may negatively affect the activity and biodiversity of microbial communities. It has been reported that antibiotics alter the number of bacterial and fungal cells, the rate of soil respiration, carbon mineralization, and nitrogen cycling (Čermák et al., 2008; Conkle and White, 2012; Rosendahl et al., 2012; Banerjee and D'Angelo, 2013; Cui et al., 2013). A key factor that determines the adverse impact of antibiotics on soil microorganisms is their persistence. The half-life of various antibiotics in soils, which depends both on the antibiotic properties and soil characteristics, varied from a few days to as many as 300 days (Hektoen et al., 1995; Weerasinghe and Towner, 1997; Ingerslev and Halling-Sorensen, 2001; Gartiser et al., 2007). The important antibiotic properties include their molecular structure, photo stability, water solubility, biodegradability, and their ability to bind to the soil matrix (Sukul et al., 2008; Förster et al., 2009; Figueroa-Diva et al.,
2010; Hu et al., 2010; Fatta-Kassinos et al., 2011; Kwon, 2011).

One of the antibiotics that has been used for more than 60 years is vancomycin. It is a bactericidal glycopeptide used to manage severe Gram-positive infections including septicemia, bone infections, lower respiratory tract infections, skin and skin structure infections. Vancomycin exhibits its antibacterial activity by inhibiting the later stages of cell wall synthesis, and thus affects dividing bacteria (Gupta et al., 2011). When vancomycin binds to the D-alanyl-D-alanine residue of pentapeptide, it blocks the addition of late precursors to the peptidoglycan (PG) chain and inhibits the subsequent cross-linking of PG (Courvalin, 2006). However, in recent years bacteria with the reduced susceptibility to vancomycin has been isolated in many countries all over the world (Sujatha and Praharaj, 2012). Moreover, the first resistant strain of vancomycin-resistant $S$. aureus was reported in 2002 (Chang et al., 2003). The basic mechanisms of vancomycin resistance involve the synthesis of precursors with low-affinity to antibiotics and the removal of the vancomycin-binding target through the elimination of the high-affinity precursors (Arthur et al., 1996). Vancomycin has been detected at concentrations reaching a concentration of $37.3 \mu \mathrm{g} / \mathrm{L}$ in hospital effluents (Passerat et al., 2010) and at a concentration of $24 \mathrm{ng} / \mathrm{L}$ in waste water effluents (Zuccato et al., 2010). During the activated sludge process in WWTPs, only $52 \%$ of the vancomycin is eliminated (Li and Zhang, 2011), and therefore, it has been found at concentrations ranging from 0.44 to $5.17 \mathrm{ng} / \mathrm{L}$ in surface water. Moreover, several reports have documented the presence of vancomycin-resistant bacteria in municipal WWTPs, effluents from hospital and surface water (Nagulapally et al., 2009; Łuczkiewicz et al., 2010; Morris et al., 2012).

Soil microbial communities play a critical role in the proper functioning of the environment and the characterization of these communities exposed to antibiotics and/or antibioticresistant bacteria will provide valuable information for the sustainable management and quality of soil. The presence and accumulation of vancomycin and other antibiotics in soil may have a deleterious effect on microbial communities and

TABLE 1 | General characteristic of the soil used in the experiment.

\begin{tabular}{lc}
\hline Parameter & Value \\
\hline Sand $(2000-50 \mu \mathrm{m})(\%)$ & $67.0 \pm 4.2$ \\
Silt $(<50-2 \mu \mathrm{m})(\%)$ & $24.0 \pm 1.1$ \\
Clay $(<2 \mu \mathrm{m})(\%)$ & $9.0 \pm 1.3$ \\
Density $\mathrm{g} / \mathrm{cm}^{3}$ & $1.35 \pm 0.08$ \\
$\mathrm{pH}_{\text {(in water) }}(1: 5)$ & $6.9 \pm 0.3$ \\
Cation exchange capacity (CEC) $(\mathrm{cmol}+/ \mathrm{kg})$ & $10.0 \pm 0.5$ \\
Water holding capacity $(\mathrm{WHC})(\%)$ & $43.0 \pm 1.2$ \\
Corg $_{\text {or }}(\%)$ & $1.6 \pm 0.2$ \\
$\mathrm{~N}_{\text {tot }}(\%)$ & $0.15 \pm 0.02$ \\
Microbial biomass $(\mathrm{mg} / \mathrm{kg})$ & $932 \pm 21$ \\
\hline
\end{tabular}

The values are the means of three replicates with the standard deviation, which was within $5 \%$ of the mean. 
cause long-lasting changes. There is still little information related to the effect of vancomycin and vancomycin-resistant bacteria on the total microbial community structure in soil. Therefore, the objective of the present study was to determine the structural and genetic diversity of a soil microbial community as determined by the phospholipid fatty acid (PLFA) and the denaturing gradient gel electrophoresis (DGGE) methods in vancomycin and/or vancomycin-resistant bacteria-treated soil.

\section{MATERIALS AND METHODS}

\section{Isolation of Vancomycin-Resistant Bacteria}

Raw sewage collected from the municipal sewage treatment plant "Gigablok" located in Katowice-Szopienice, southern Poland was the source of the bacterial strains that are resistant to vancomycin. The isolation procedure was performed using a TSA (Tryptone-Soya Agar) medium (BTL, Poland) and paper discs impregnated with $30 \mu \mathrm{g}$ vancomycin (VA) (Oxoid, UK). The inoculated plates were incubated for $48 \mathrm{~h}$ at $30 \pm 1{ }^{\circ} \mathrm{C}$. In order to obtain a pure culture of vancomycin-resistant bacteria, colonies located directly on the shore disc were transferred onto a new TSA medium and incubated under the same conditions. The individual bacterial colonies were selected and subcultured to obtain pure culture based on their morphological properties. One bacterial isolate was used for further analyses.

\section{Identification of Bacteria}

The isolate was characterized and identified using a biochemical test and 16S rRNA gene analysis as it was previously described by Cycoń et al. (2014). The biochemical properties of the isolate and the substrate utilization pattern were determined using an API 20E System (bioMérieux Inc., France) according to the manufacturer's recommendations. For the $16 \mathrm{~S}$ rRNA sequence analysis, the genomic DNA was extracted from a strain collected at the late exponential stage of growth using a GeneMATRIX Bacterial and Yeast Genomic DNA Purification Kit (Eurx, Poland) as described in the protocol of the manufacturer. The 16S rRNA gene of the isolate was amplified using the universal primer pair: 27f ( $5^{\prime}$-AGA GTT TGA TCC TGG CTC AG-3') and1492r (5'-TAC GGT TAC CTT GTT ACG ACT T-3'; Lane, 1991) obtained from Sigma-Aldrich (Germany). Amplification was performed using a PCR Master Mix Kit (Promega) according to the manufacturer's recommendations and a PTC-118 Thermal Cycler (Bio-Rad, CA, USA) under the following conditions: (i) an initial denaturation step of $95^{\circ} \mathrm{C}$ for $2 \mathrm{~min}$, (ii) 30 cycles of denaturation, annealing, and extension $\left(95^{\circ} \mathrm{C}\right.$ for $1 \mathrm{~min}$ followed by $54^{\circ} \mathrm{C}$ for $30 \mathrm{~s}$, with an extension step at $72^{\circ} \mathrm{C}$ for $2 \mathrm{~min}$ ), and (iii) a final extension at $72^{\circ} \mathrm{C}$ for $5 \mathrm{~min}$. After amplification the products were purified with a GeneMATRIX PCR/DNA Clean-Up Purification Kit (Eurx, Poland) according to the protocol of the manufacturer before the amplicons were sequenced. Gene sequencing was

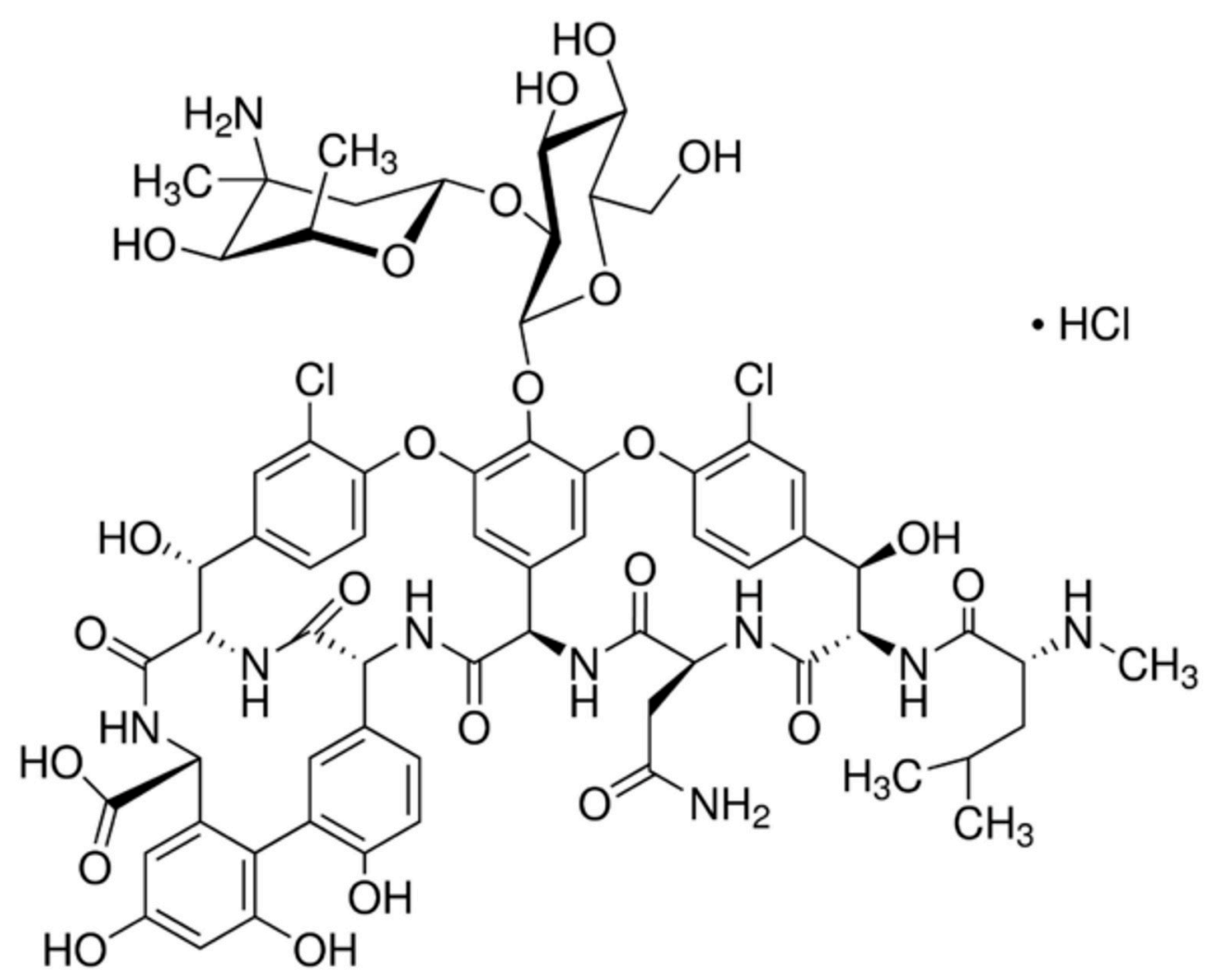

FIGURE 1 | Chemical structure of vancomycin. 
performed using a Big Dye ${ }^{\circledR}$ Terminator Cycle Sequencing Kit (Applied Biosystem) and an AbiPrism ${ }^{\circledR} 3100$ Genetic Analyzer. The obtained sequence was compared to known 16S rRNA gene sequences using the BLAST server at the National Center for Biotechnology Information (NCBI; http://www.ncbi.nlm. nih.gov/). DNA sequences were aligned using CLUSTAL W. Phylogenetic analysis was performed by the neighbor-joining (NJ) method, which tests the support for the phylogeny with a bootstrap analysis based on 1000 replicates using the MEGA ver. 6.0 software.

\section{Determination of the Susceptibility of Bacteria to Selected Antibiotics}

The sensitivity assays to vancomycin and other selected antibiotics for isolated bacterial strain were performed on a Mueller-Hinton agar (BTL, Poland) using the Kirby-Bauer disc diffusion and the E-test methods according to the protocols for determining the zones of growth inhibition and the values of the minimum inhibitory concentrations (MICs), respectively. In order to prepare the inoculum, the bacterial strain were cultured on nutrient agar (BTL, Poland) for $24 \mathrm{~h}$ at $35 \pm 1^{\circ} \mathrm{C}$, and at the exponential phase, the bacteria were suspended in $0.85 \%$ sterile
$\mathrm{NaCl}$ to obtain the bacterial suspension at a concentration of $\sim 1.5 \times 10^{8}$ cells $/ \mathrm{mL}$. The cell density (OD $550 \mathrm{~nm}$ ) was measured using a densitometer (Densimat ${ }^{\circledR}$, bioMérieux, France). Next, the bacterial suspension was inoculated on a Mueller-Hinton agar using a sterile cotton swab. In the case of the disc diffusion method, the paper discs impregnated with ciprofloxacin (CI: $5 \mu \mathrm{g}$ ), clindamycin (CM: $2 \mu \mathrm{g}$ ), erythromycin (EM: $15 \mu \mathrm{g}$ ), streptomycin (SM: $300 \mu \mathrm{g}$ ), tetracycline (TC: $30 \mu \mathrm{g}$ ), vancomycin (VA: $30 \mu \mathrm{g}$ ), or cefuroxime (XM: $30 \mu \mathrm{g}$ ) obtained from Oxoid (UK), were applied to the surface of an agar plate inoculated with the test strain. The inoculated plates were incubated for $24 \mathrm{~h}$ at $35 \pm 1^{\circ} \mathrm{C}$, after which, the diameters of the zones of growth inhibition around each disc were measured. In the case of the $E$-test method, strips with a defined gradient of ciprofloxacin (CI: $0.002-32 \mu \mathrm{g} / \mathrm{mL}$ ), clindamycin (CM: 0.016-256 $\mu \mathrm{g} / \mathrm{mL}$ ), erythromycin (EM: 0.016-256 $\mu \mathrm{g} / \mathrm{mL}$ ), streptomycin (SM: 0.064-1024 $\mu \mathrm{g} / \mathrm{mL}$ ), tetracycline (TC: $0.016-$ $256 \mu \mathrm{g} / \mathrm{mL}$ ), vancomycin (VA: $0.016-256 \mu \mathrm{g} / \mathrm{mL}$ ), or cefuroxime (XM: $0.016-256 \mu \mathrm{g} / \mathrm{mL}$ ) obtained from bioMérieux (France) were applied to the surface of the agar plate inoculated with the test strain. The inoculated plates were incubated for $48 \mathrm{~h}$ at $35 \pm$ $1^{\circ} \mathrm{C}$. The MIC values were read from the scale in terms of $\mu \mathrm{g} / \mathrm{mL}$ at the site where the ellipse edge intersected with the strip.

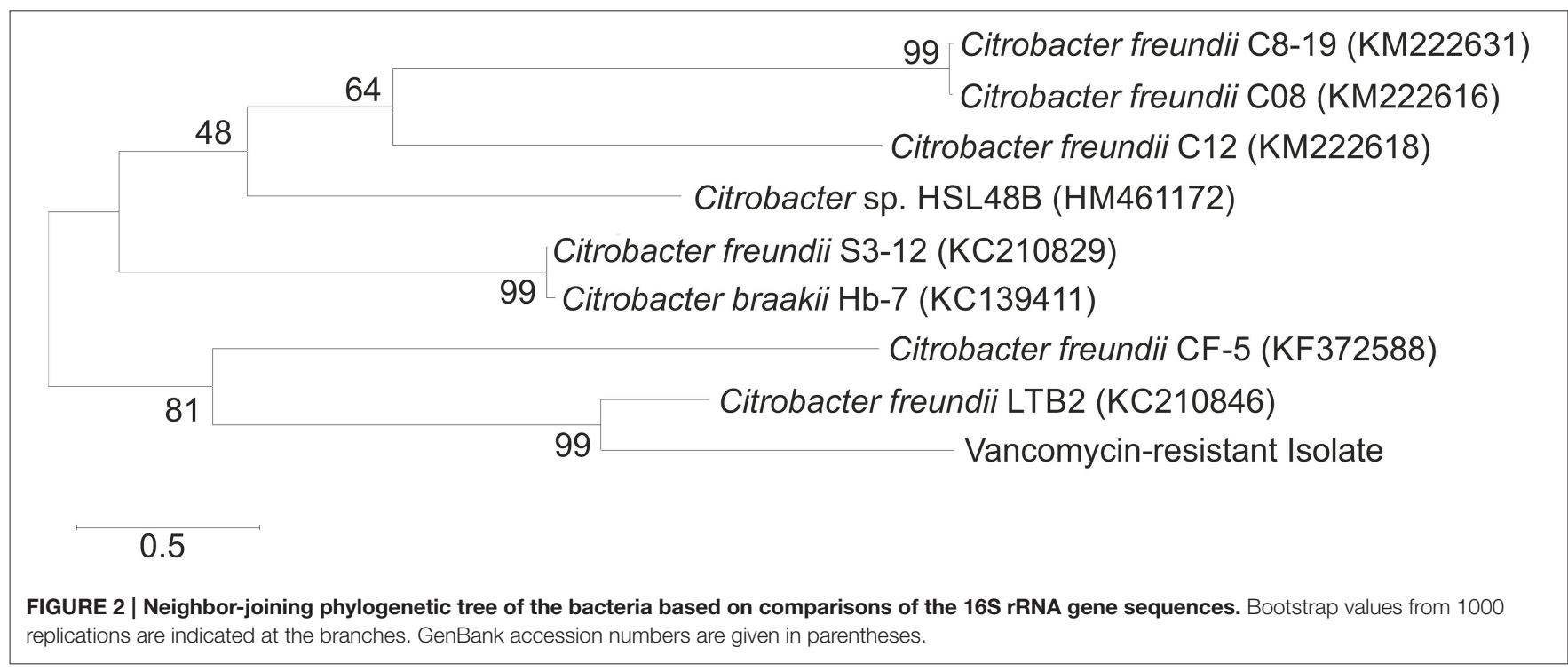

TABLE 2 | Biochemical pattern of bacterial strain isolated from raw sewage.

\begin{tabular}{lclll}
\hline Characteristics & Results & Characteristics & Results & Characteristics \\
\hline 2-Nitrophenyl- $\beta$-D-galactopyranoside & + & L-Tryptophane (deaminase) & - & D-Sorbitol \\
L-Arginine & + & L-TRYPTOPHANE (indol) & - & L-Rhamnose \\
L-Lysine & - & Sodium pyruvate & - & D-Sacharose (sucrose) \\
L-Ornithine & - & Gelatin & - & D-Melibiose \\
Trisodium citrate & + & D-Glucose & + & Amygdalin \\
Sodium thiosulfate & + & D-Mannitol & + & L-Arabinose \\
Urea & - & Inositol & + & Oxidase \\
\hline
\end{tabular}

+ , tested positive; -, tested negative. 


\section{Soil Characteristics}

Sandy loam soil samples were collected from the top layer (0$20 \mathrm{~cm}$ ) from grass-covered fields located in the vicinity of Żywiec, southern Poland. The detailed physico-chemical properties of the soil (Table 1) were determined according to ISO standards as presented in previous paper (Cycoń et al., 2010). In the laboratory, the soil was sieved to a maximum particle size of $<2 \mathrm{~mm}$ and immediately used for the experiment.

\section{Experimental Design and Treatments}

The European Pharmacopeia (EP) reference standard of vancomycin $\left(\mathrm{C}_{66} \mathrm{H}_{75} \mathrm{Cl}_{2} \mathrm{~N}_{9} \mathrm{O}_{24}\right.$. $\mathrm{HCl}$; Figure 1) purchased from Sigma-Aldrich (Germany) was used in this study. The experiment had a completely randomized block design with the following treatments: control soil (C), soil with vancomycin $(1 \mathrm{mg} / \mathrm{kg}$ soil-VA1), soil with vancomycin $(10 \mathrm{mg} / \mathrm{kg}$ soilVA10), soil inoculated with Citrobacter freundii $\left(1.6 \times 10^{7}\right.$ cells/g soil; Cit), soil with vancomycin ( $1 \mathrm{mg} / \mathrm{kg}$ soil) and with $C$. freundii $\left(1.6 \times 10^{7}\right.$ cells/g soil; VA1+Cit), and soil with vancomycin $(10 \mathrm{mg} / \mathrm{kg}$ soil $)$ and C. freundii $\left(1.6 \times 10^{7}\right.$ cells/g soil; VA10+Cit). There were three replications of each treatment for each sampling time, which produced a total of 90 pots in the experiment (i.e., six treatments $\times$ three replications $\times$ five sampling times). In order to ensure an even distribution of the antibiotic in the soil, the VA solution was prepared in sterile pure water and then added to sterile quartz sand $(<0.5 \mathrm{~mm})$. After evaporation of water in the dark, the mixture of sand $(50 \mathrm{~g} / \mathrm{kg}$ soil) and VA was added into the soil portion and thoroughly mixed. The concentrations of vancomycin that were used reflect the most adverse scenarios associated with the entry of large quantities of antibiotics into the soil as a result of the uncontrolled disposal of unused drugs into municipal waste or depositing them in landfills.

In order to prepare the inoculum, the bacterial strain was cultured in $200 \mathrm{~mL}$ Erlenmeyer flasks containing $100 \mathrm{~mL}$ of nutrient broth (BTL, Poland). At the exponential phase, the bacteria were pelleted by centrifugation ( $5 \mathrm{~min}, 10,000 \mathrm{~g}$ ). The pellet was washed twice with $0.85 \%$ of sterile $\mathrm{NaCl}$ and then resuspended in $0.85 \%$ of sterile $\mathrm{NaCl}$ to obtain a bacterial suspension at a concentration of $\sim 2.1 \times 10^{9}$ cells $/ \mathrm{mL}$. The cell density (OD $550 \mathrm{~nm}$ ) was measured using a densitometer (Densimat ${ }^{\circledR}$, bioMérieux, France). Next, the bacterial suspension was introduced into the soil in triplicate in order to produce a final bacterial count of $\sim 1.6 \times 10^{7}$ cells/g soil.

The water content of the soils was adjusted to $50 \%$ of the maximum water holding capacity and maintained at this level during the experimental period. The pots were covered with perforated polypropylene sheets and were incubated in the dark at $22 \pm 1^{\circ} \mathrm{C}$ for 90 days. Soil samples were periodically taken (on days $1,15,30,60$, and 90) for the determination of the genetic and structural diversity of the microbial communities.

\section{Analysis of the Soil Microbial Community Structure Using the PCR-DGGE Method}

Total DNA was extracted from the soil samples using a GeneMATRIX Soil DNA Purification Kit (Eur ${ }_{\mathrm{x}}$, Poland) as described in the protocol of the manufacturer and subjected to electrophoresis in $1 \%(\mathrm{w} / \mathrm{v})$ agarose gel followed by quantification using a Biophotometer (Eppendorf, Germany). A fragment of the V3 region of the bacterial 16S RNA gene was amplified using the primers F338 (5'-ACT CCT ACG GGA GGC AGC AG-3') and R518 (5'-ATT ACC GCG GCT GCT GG-3'). The forward primers contained a 40-bp GC-clamp (5'-CGC CCG CCG CGC GCG GCG GGC GGG GCG GGG GCA CGG GGG G-3') attached to the $5^{\prime}$ end (Muyzer et al., 1993). The PCR reaction mixture contained $1 \times$ GoTaq Flexi Buffer (Promega), $2 \mathrm{mM} \mathrm{MgCl} 2,0.2 \mathrm{mM}$ dNTP Mix (Promega), $0.5 \mu \mathrm{M}$ of each primer (Sigma-Aldrich), $0.2 \mu \mathrm{g}$ of DNA, and $1.5 \mathrm{U} / \mu \mathrm{L}$ GoTaq DNA Polymerase (Promega). PCR was carried out using a PTC-118 Thermal Cycler (BIO-RAD, CA, USA) as follows: (i) an initial denaturation step of $95^{\circ} \mathrm{C}$ for $10 \mathrm{~min}$, (ii) 30 cycles of denaturation, annealing, and extension $\left(95^{\circ} \mathrm{C}\right.$ for $1 \mathrm{~min}$ followed by $53^{\circ} \mathrm{C}$ for $1 \mathrm{~min}$ with an extension step at $72^{\circ} \mathrm{C}$ for $2 \mathrm{~min}$ ), and (iii) a final extension at $72^{\circ} \mathrm{C}$ for $12 \mathrm{~min}$.

After amplification the products were purified using a QIAquick PCR Purification Kit (Qiagen, USA) according to the protocol of the manufacturer and then analyzed in $8 \%$ $(\mathrm{w} / \mathrm{v})$ polyacrylamide gel (37.5:1 acrylamide:bis-acrylamide),

TABLE 3 | Results of susceptibility of isolated Citrobacter freundii to selected antibiotics.

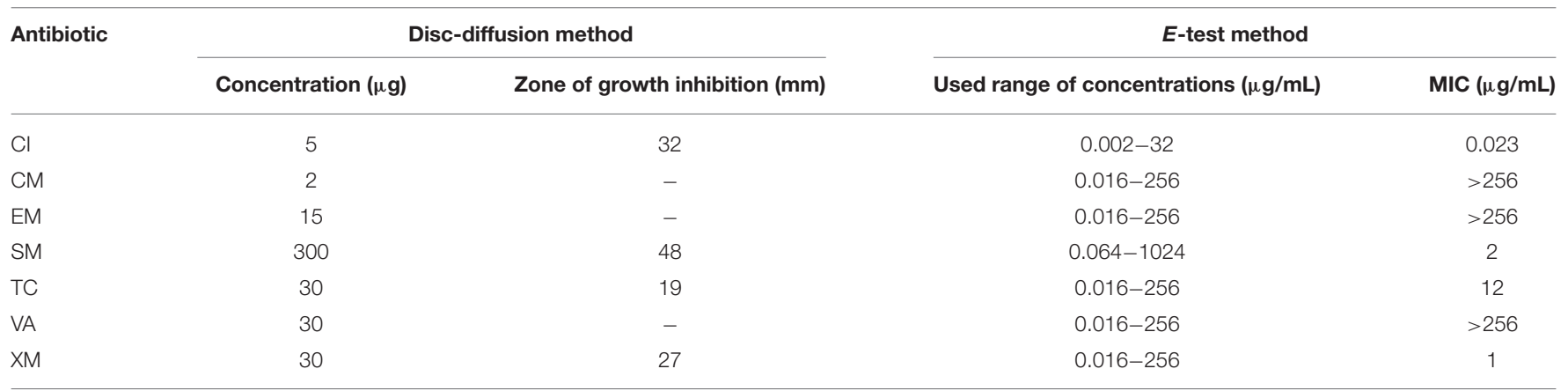

Cl, ciprofloxacin; CM, clindamycin; EM, erythromycin; SM, streptomycin; TC, tetracycline; VA, vancomycin; XM, cefuroxime, -, no inhibition zone. Values of the inhibition zones and MICs (minimum inhibitory concentrations) were determined after 24 and $48 \mathrm{~h}$ of incubation, respectively. 

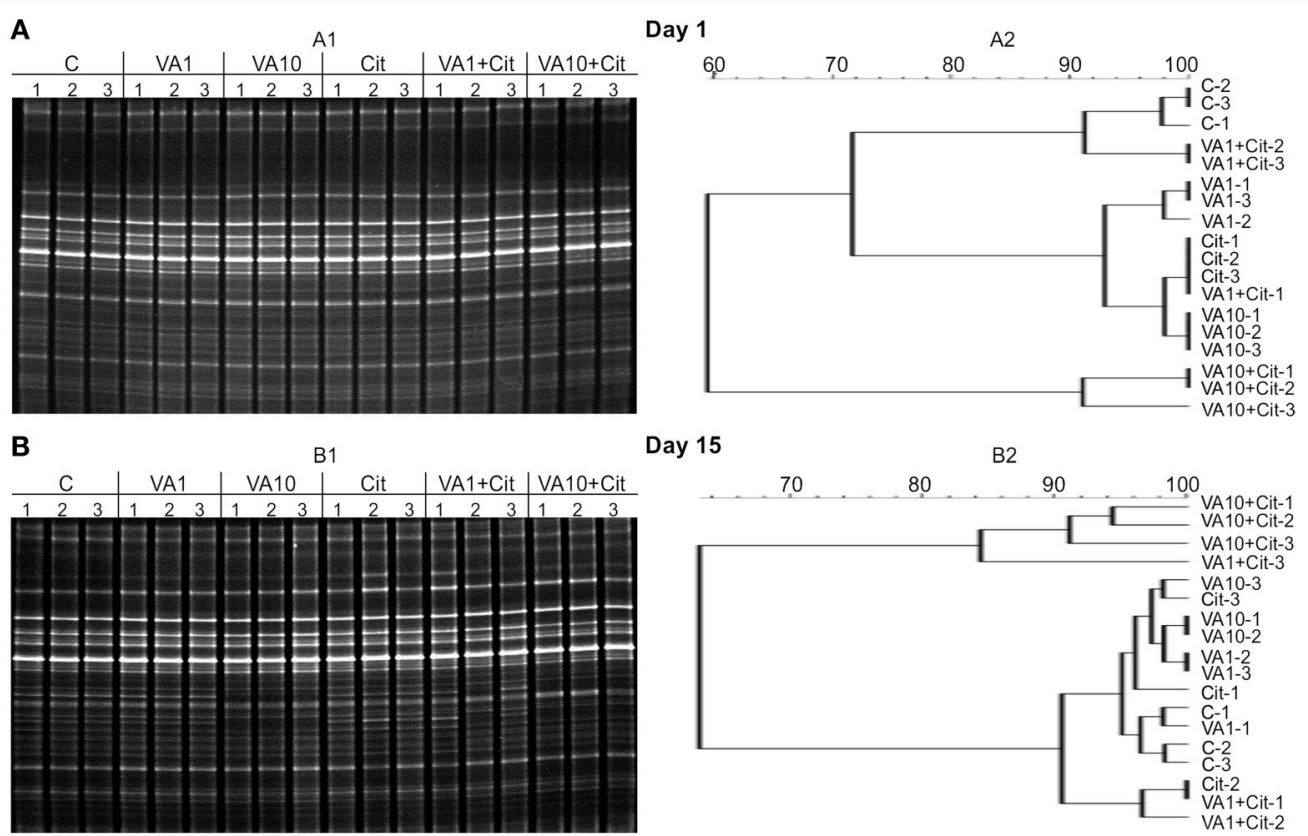

Day 15

B2
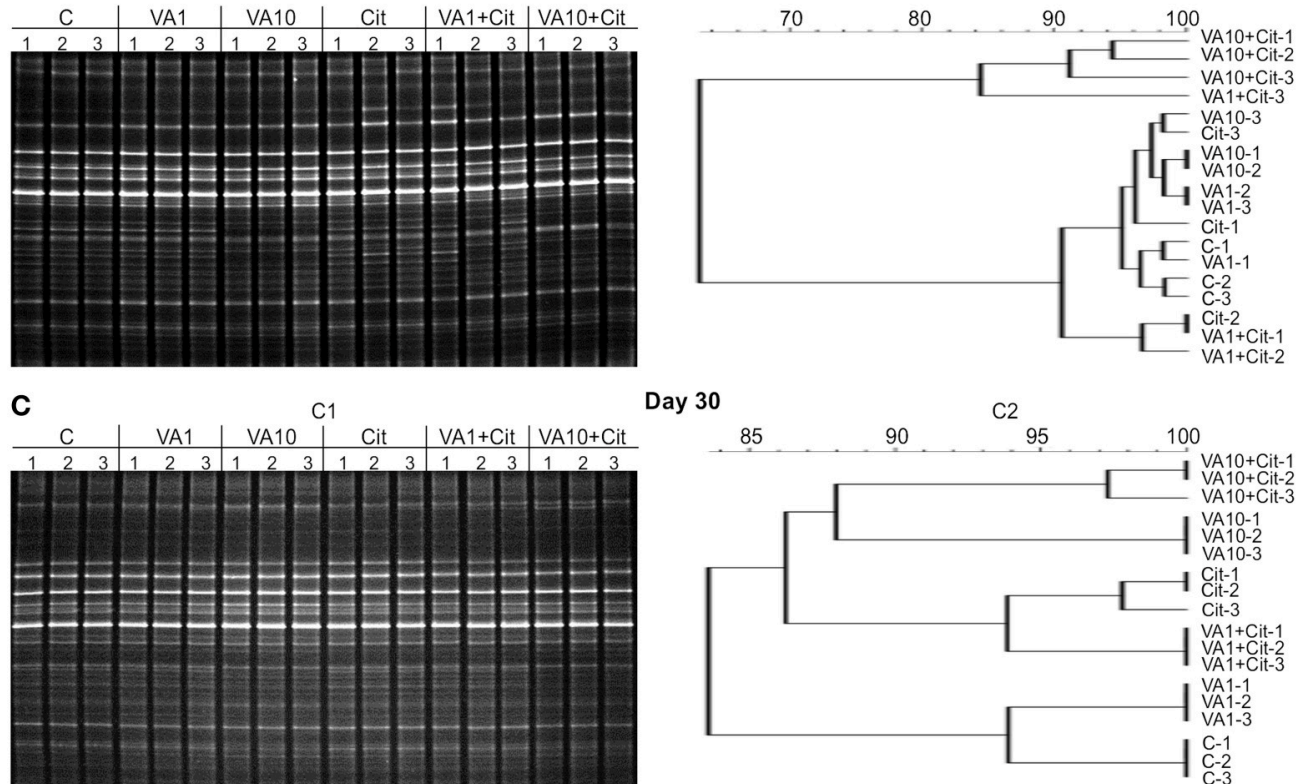

Day 30 VA1+Cit-2
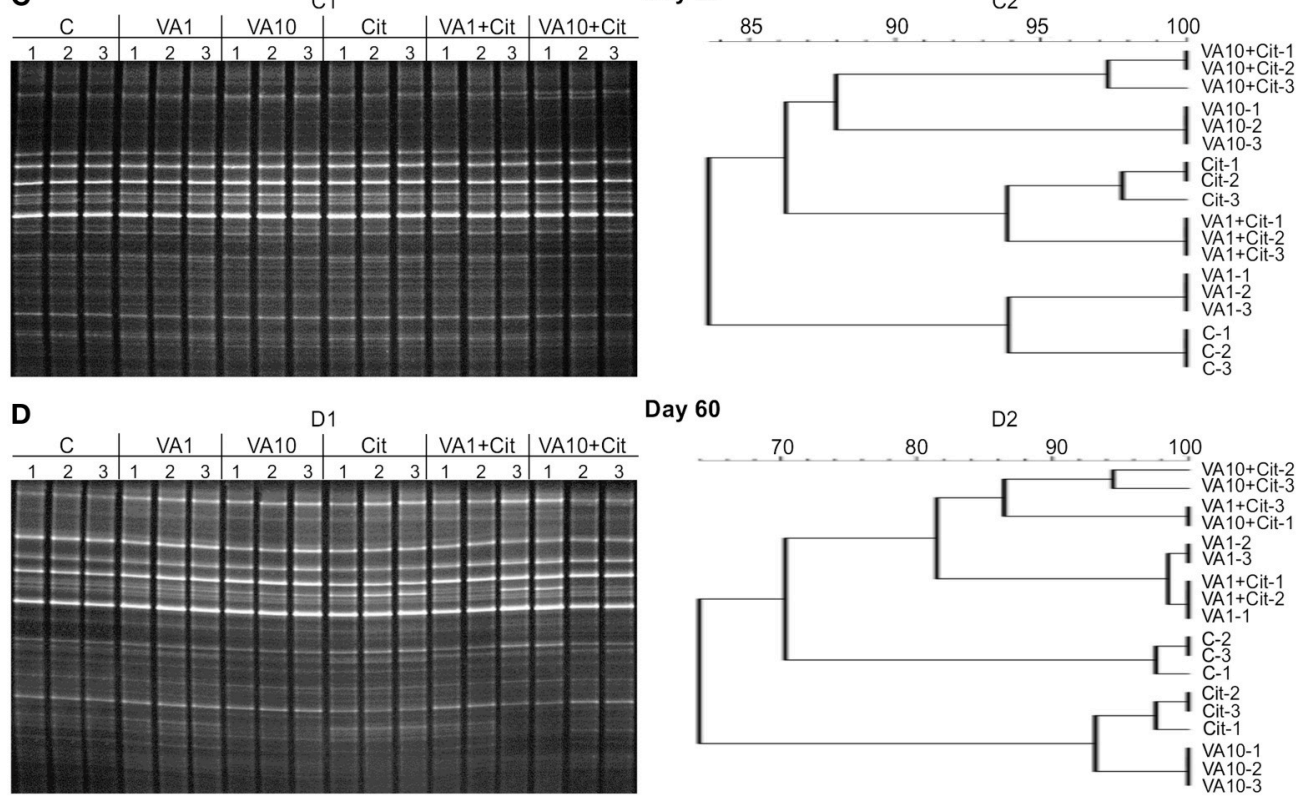

Day 60

D2
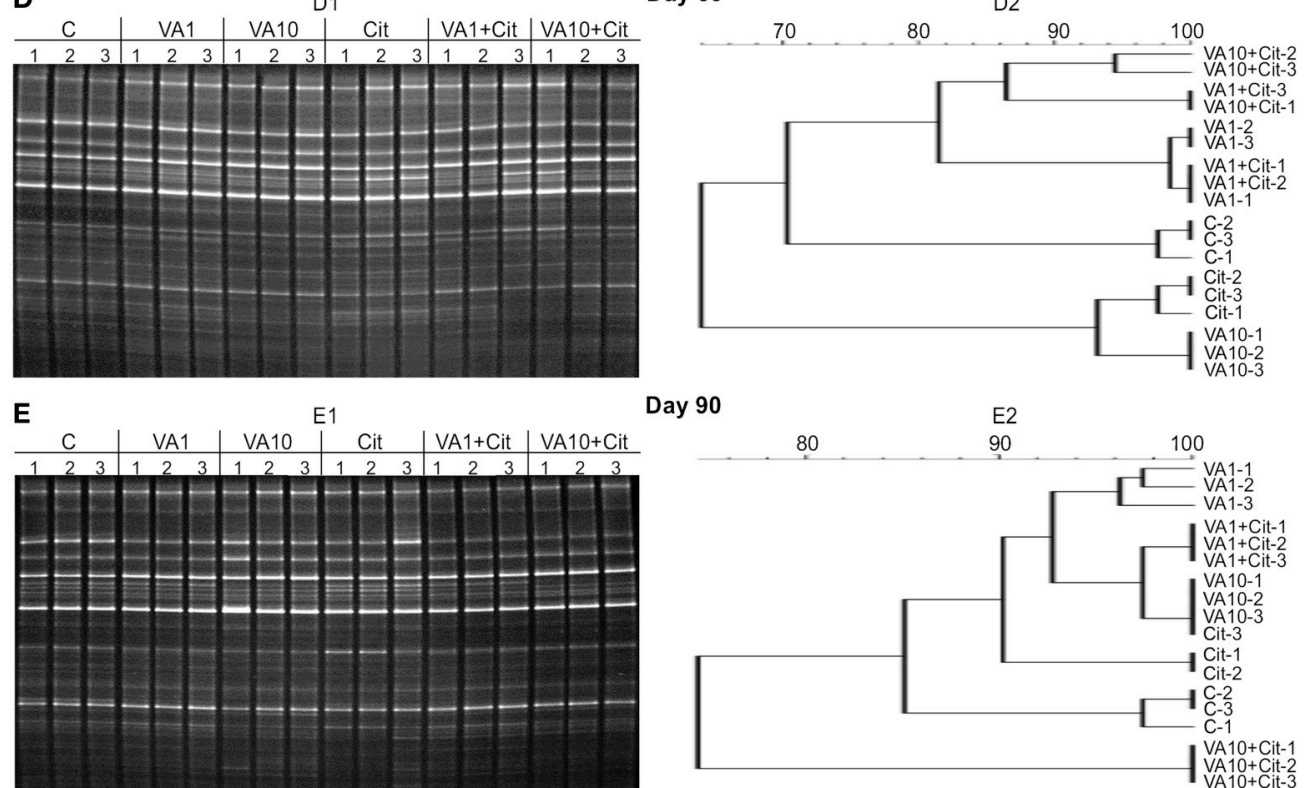

Day 90

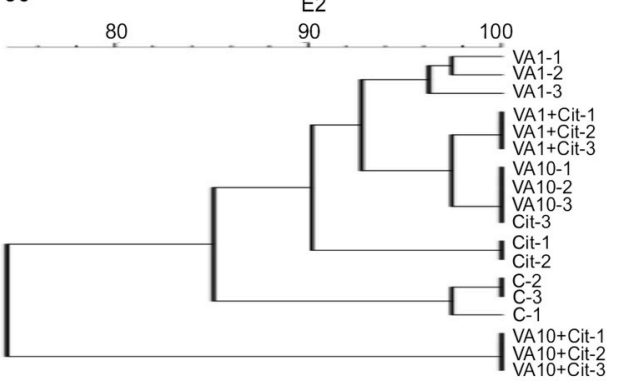

FIGURE 3 | DGGE profiles (A1-E1) and phylogenic dendrograms (A2-E2) for PCR-amplified fragments of the 16S rRNA gene for soil treated with vancomycin (VA) and/or Citrobacter freundii (Cit) on days 1 (A), 15 (B), 30 (C), 60 (D), and 90 (E) following treatment (C, control; VA1, 1 mg/kg soil; VA10, $10 \mathrm{mg} / \mathrm{kg}$ soil). 

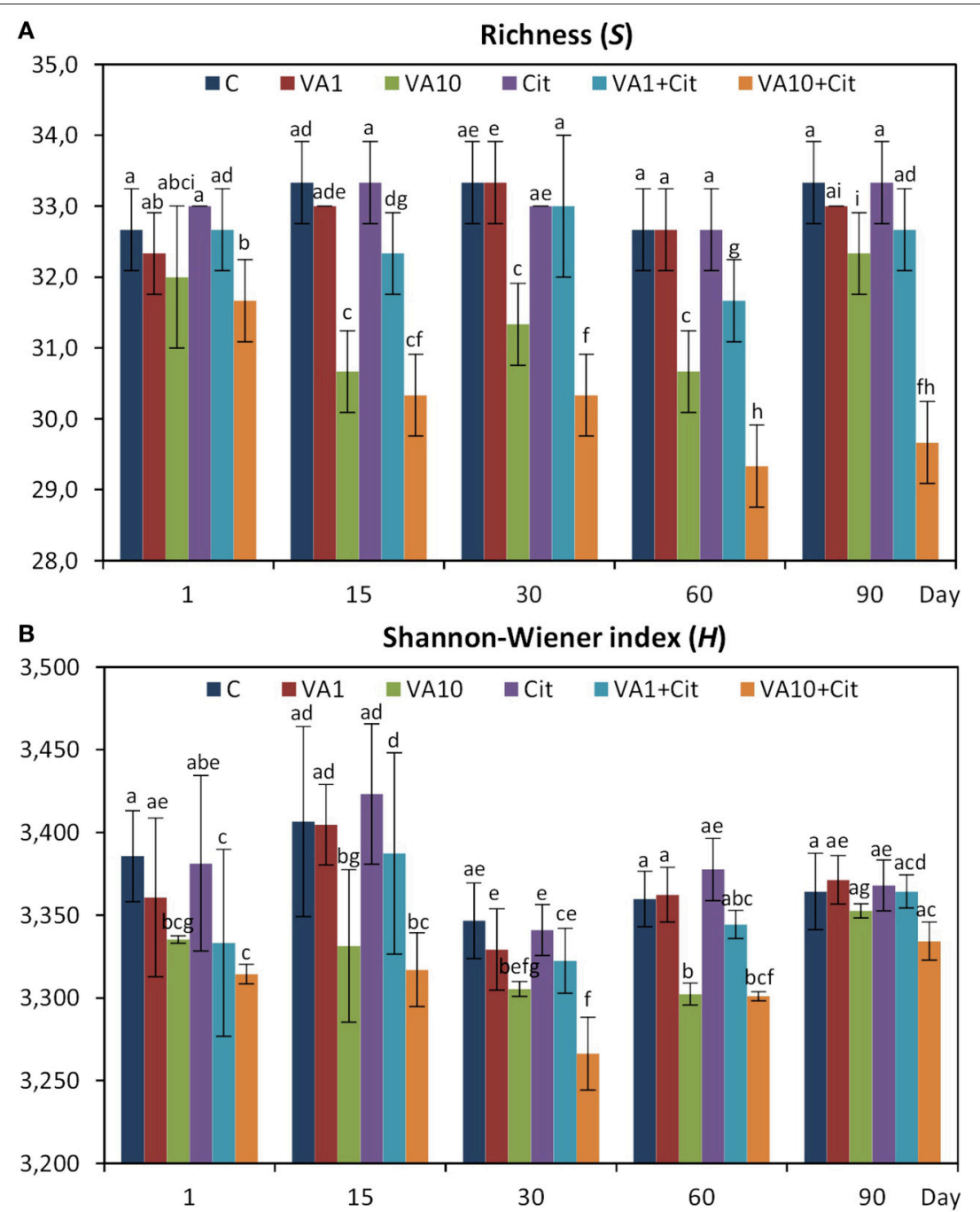

C

Evenness $\left(E_{H}\right)$

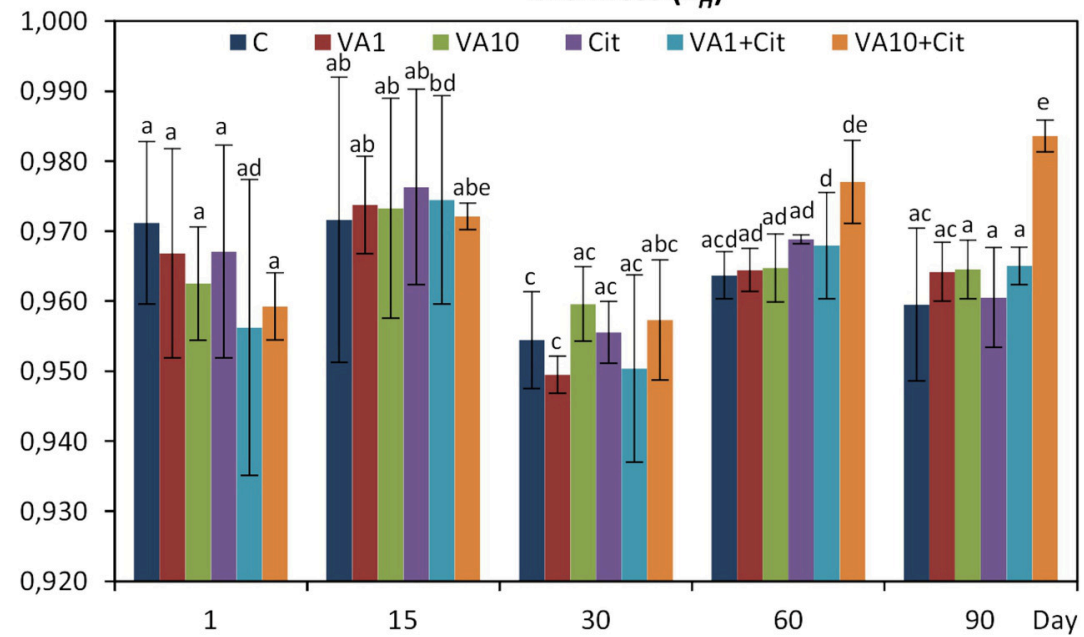

FIGURE 4 | Results of the DGGE analysis $-H$, Shannon-Wiener index (A); $R$, richness (B); and $E_{H}$, evenness (C) for the control soil (C), soil with vancomycin (1 mg/kg soil)(VA1), soil with vancomycin (10 mg/kg soil)(VA10), soil with Citrobacter freundii (Cit), soil with vancomycin (1 mg/kg soil) and Citrobacter freundii (VA1+Cit) and soil with vancomycin (10 mg/kg soil) and Citrobacter freundii (VA10+Cit). The data presented are the means and standard deviations of three replicates. Different letters (within each index) indicate significant differences $(P<0.05$, LSD test) related to the effects of the antibiotic dosage, bacterial strain, and time. 
composed of a linear denaturing gradient ranging from 40 to $70 \%$. Denaturant solutions were prepared by mixing the appropriate volumes of two (0-100\%) denaturant stock solutions ( $7 \mathrm{~mol} / \mathrm{L}$ urea and $40 \% \mathrm{v} / \mathrm{v}$ formamide). The electrophoresis was run at $60^{\circ} \mathrm{C}$ in a $1 \times \mathrm{TAE}$ buffer for $14 \mathrm{~h}$ at a constant voltage of $80 \mathrm{~V}$ using a DCode Mutation Detection System (Bio-Rad, USA). After this, the gels were stained with ethidium bromide $(0.5 \mathrm{mg} / \mathrm{mL})$ and visualized on a UV trans illuminator.

The DGGE profiles were analyzed using BioNumerics software ver. 7.5 (Applied Math, Belgium). The similarity values of each DGGE band was calculated by applying the Dice coefficient. Based on the presence/absence of a band and band weighting (band density) analyses, phylogenic dendrograms were constructed using the unweighted pair-group method and the arithmetic averages (UPGMA). Richness $(S)$ values were calculated as the number of DNA bands detected in the respective lines of the DGGE profile, while the Shannon-Wiener index $(H)$, and evenness $\left(E_{H}\right)$ values were calculated according to the Equations (1) and (2), respectively.

$$
\begin{aligned}
H & =-\Sigma p i(\ln p i) \\
E_{H} & =\frac{H}{H_{\max }}=\frac{H}{\ln S}
\end{aligned}
$$

where $p_{i}$ is the ratio between the specific band intensity and the total intensity of all of the bands and $S$ is the total number of bands in each sample.

\section{Analysis of the Soil Microbial Community Structure Using the PLFA Method}

The community structure of the total microbial community was assessed using a slightly modified protocol for a PLFA analysis by Frostegård et al. (1993). Briefly, the lipids from $2 \mathrm{~g}$ of soil were extracted using a solution containing a chloroform:methanol:citric buffer $(1: 2: 0.8 \mathrm{v} / \mathrm{v} / \mathrm{v})$ and separated into neutral, glycolipid and phospholipid fractions in silicic acid columns (Supelco Silica Tube, $3 \mathrm{~mL}, 500 \mathrm{mg}$ ). In order to obtain the fatty acid methyl esters (FAMEs), the phospholipids were subjected to a mild alkaline methanolysis. FAMEs were subsequently analyzed using an Agilent 7820A GC gas chromatograph system with an Agilent HP-Ultra 2 capillary column (cross-linked 5\% phenyl-methyl silicone; $25 \mathrm{~m}, 0.20 \mathrm{~mm}$ ID; film thickness $0.33 \mu \mathrm{m}$ ) with hydrogen as the carrier gas. FAMEs were detected using a flame ionization detector (FID) and identified using the MIDI Microbial Identification System software (Sherlock TSBA6 library; MIDI Inc., Newark, DE, USA). Nonadecanoic acid (19:0) was used as the internal standard for the fatty acid quantitative analysis. Total PLFA biomass was calculated by summing all of the isolated fatty acids. Bacterial biomass was calculated based on fatty acids of a bacterial origin. The community structure analysis was based on the fatty acids that are thought to be the biomarkers of Gram-positive bacteria (i15:0, a15:0, i16:0, i17:0, a17:0) and Gram-negative bacteria $(16: 1 \omega 7 \mathrm{t}, 18: 1 \omega 7$, cy19:0, cy17:0). The distribution of $18: 2 \omega 6$ as well as $10 \mathrm{Me} 17: 0$ and $10 \mathrm{Me} 18: 0$, was used to determine

\begin{tabular}{|c|c|c|c|c|c|c|c|}
\hline Parameter & Source of variation & $d f$ & Sum of squares & Mean squares & Variance explained (\%) & $\boldsymbol{F}$ & $\boldsymbol{P}$ \\
\hline \multirow[t]{5}{*}{ Richness (S) } & Strain (S) & 1 & 5.88 & 5.88 & 4 & 17.6 & $P<0.001$ \\
\hline & Concentration (C) & 2 & 85.09 & 42.54 & 61 & 127.6 & $P<0.001$ \\
\hline & Time (T) & 4 & 8.18 & 2.04 & 6 & 6.1 & $P<0.001$ \\
\hline & $\mathrm{S} \times \mathrm{C}$ & 2 & 4.96 & 2.48 & 4 & 7.4 & $P=0.001$ \\
\hline & $\mathrm{S} \times \mathrm{T}$ & 4 & 3.29 & 0.82 & 2 & 2.5 & $P=0.054$ \\
\hline \multirow[t]{4}{*}{ Shannon-Wiener index $(H)$} & Strain (S) & 1 & 0.002 & 0.002 & 1 & 2.4 & $P=0.129$ \\
\hline & Concentration (C) & 2 & 0.056 & 0.028 & 35 & 32.7 & $P<0.001$ \\
\hline & Time (T) & 4 & 0.035 & 0.009 & 22 & 10.3 & $P<0.001$ \\
\hline & $\mathrm{S} \times \mathrm{C}$ & 2 & 0.003 & 0.001 & 2 & 1.5 & $P=0.224$ \\
\hline \multirow[t]{7}{*}{ Evenness $\left(E_{H}\right)$} & Strain (S) & 1 & 0.00008 & 0.00008 & 1 & 0.8 & $P=0.378$ \\
\hline & Concentration (C) & 2 & 0.00026 & 0.00013 & 2 & 1.3 & $P=0.277$ \\
\hline & Time $(T)$ & 4 & 0.00352 & 0.00088 & 30 & 8.9 & $P<0.001$ \\
\hline & $\mathrm{S} \times \mathrm{C}$ & 2 & 0.00013 & 0.00007 & 1 & 0.7 & $P=0.520$ \\
\hline & $\mathrm{S} \times \mathrm{T}$ & 4 & 0.00053 & 0.00013 & 5 & 1.3 & $P=0.263$ \\
\hline & $\mathrm{C} \times \mathrm{C}$ & 8 & 0.00092 & 0.00012 & 8 & 1.2 & $P=0.332$ \\
\hline & $\mathrm{S} \times \mathrm{C} \times \mathrm{T}$ & 8 & 0.00035 & 0.00004 & 3 & 0.4 & $P=0.890$ \\
\hline
\end{tabular}

TABLE 4 | Results of three-way ANOVA for the effects of concentration of vancomycin, bacterial strain, time, and their interaction on DGGE parameters.

The effects in bold are significant at $P<0.05$. 
fungal biomass and actinomycetales, respectively (Frostegård and Bååth, 1996; Bååth and Anderson, 2003). Additionally, the ratios of the biomass of Gram-positive to the biomass of Gramnegative bacteria as well as the bacterial to fungal fraction were calculated.

\section{Statistical Analyses}

The DGGE and PLFA data were analyzed using a three-way analysis of variance (ANOVA), which allowed the percentage of the variation attributable to the antibiotic concentration, bacterial strain, and incubation time to be determined. The statistical significance of differences $(P<0.05)$ in the measured data was assessed by a post-hoc comparison of the means using the least significant differences (LSD) test. A principal component analysis (PCA) of the microbial PLFA biomarkers of Gram-positive and Gram-negative bacteria as well as fungi was carried out in two sets that included the PLFA data from all of the sampling days and were performed separately for each sampling day. The three-way and twoway MANOVA analyses of the PC scores were performed for the first and second PCA sets, respectively. The PCA analyses were performed on the standardized data. All statistical analyses were performed using the Statistica 12.0 PL software package.

TABLE 5 | The total, bacterial and fungal biomass expressed as the biomass of phospholipid fatty acid marker (nmol PLFA/g soil) in vancomycin- and/or Citrobacter freundii-treated soil.

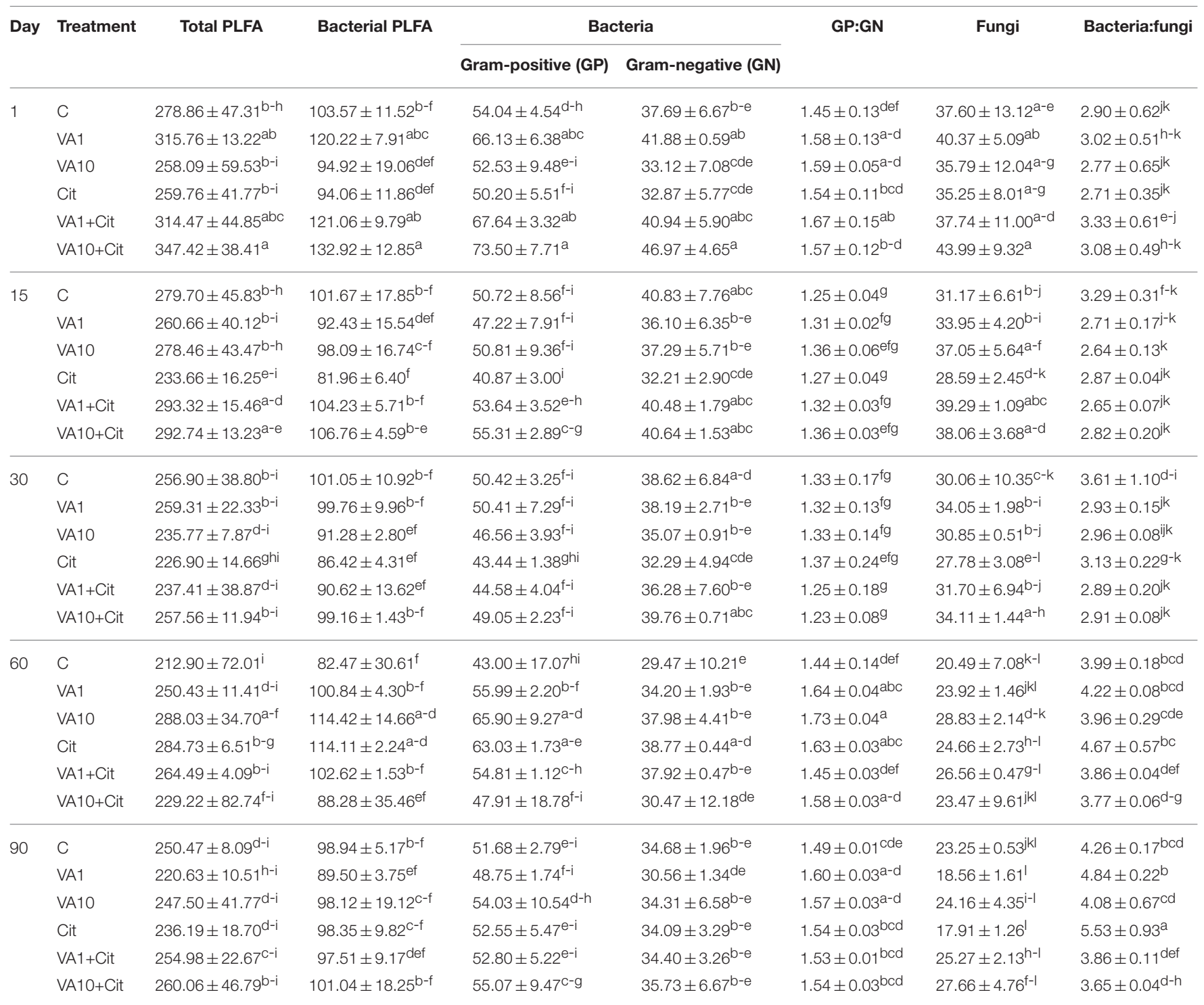

C, control soil; VA1, soil treated with vancomycin-1 mg/kg soil; VA10, soil treated with vancomycin-10 mg/kg soil; Cit, soil inoculated with C. freundii; VA1+Cit, soil treated with vancomycin $-1 \mathrm{mg} / \mathrm{kg}$ soil and inoculated with C. freundii; VA10+Cit, soil treated with vancomycin-10 mg/kg soil and inoculated with C. freundii. The data presented are the means and standard deviations of three replicates. The different letters (within each group) indicate significant differences $(P<0.05, L S D$ test), considering the effects of the antibiotic dosage, bacterial strain and time. 
TABLE 6 | Results of three-way ANOVA for the effects of concentration of vancomycin, bacterial strain, time, and their interaction on the measured biomass of PLFA markers.

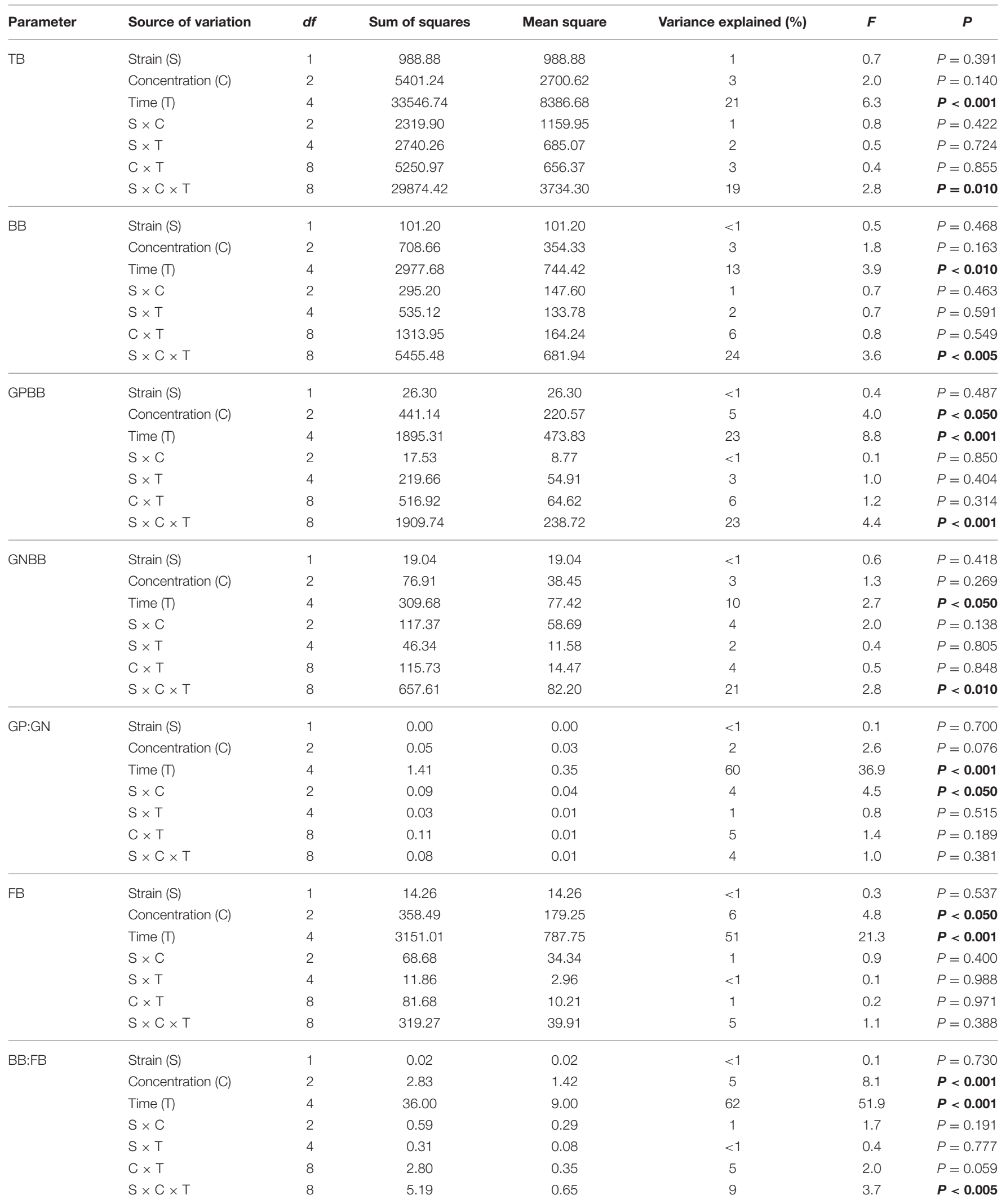

TB, total biomass; BB, bacterial biomass; GNBB, Gram-negative bacterial biomass; GPBB, Gram-positive bacterial biomass; FB, fungal biomass. The effects in bold are significant at $P<0.05$. 


\section{RESULTS}

\section{Isolation and Identification of Vancomycin-Resistant Bacteria}

The isolation procedure enabled isolation of the bacterial strain that was characterized by the tolerance to vancomycin applied at a concentration of $30 \mu \mathrm{g} / \mathrm{mL}$. After incubation on nutrient agar plates $(24 \mathrm{~h})$, the colonies of the isolated strain were observed to be creamy white. Identification based on the analysis of the partial 16S rRNA sequence allowed the isolated strain to be identified as $C$. freundii. The phylogenetic analysis showed that the 16S rRNA sequence of the isolate had a 99\% sequence similarity with C. freundii LTB2 strain (Figure 2). Analysis of the biochemical pattern using an API 20 E-test system (Table 2) allowed the numerical profile $(3,604,772)$ to be obtained, which was compared with profiles deposited in the apiweb ${ }^{\mathrm{TM}}$ database, and that also supported the reliable identification of the isolate as C. freundii with a $97.9 \%$ identity.

\section{Susceptibility of Citrobacter freundii to Selected Antibiotics}

The results obtained using the disc diffusion method showed that the isolated strain was resistant to clindamycin, erythromycin, and vancomycin as indicated by the lack of inhibition zones of bacterial growth around the discs impregnated with antibiotics at concentrations of 2,15 , and $30 \mu \mathrm{g} / \mathrm{ml}$, respectively (Table 3 ). In general, the antibiotics for which there were no zones of the inhibition of the growth of the bacterial strain using the disc diffusion method showed no growth inhibition using the E-test, and their MIC values were higher than $256 \mu \mathrm{g} / \mathrm{mL}$. On the other hand, the highest sensitivity of a bacterial strain to ciprofloxacin was determined for which the MIC value was $0.023 \mu \mathrm{g} / \mathrm{mL}$ (Table 3).

\section{DGGE Analysis}

Analysis of the DGGE patterns revealed that vancomycin and/or C. freundii affected the structure of the soil microbial community during the 90 -day experiment. The DGGE profiles generated from the replicates for all of the treatments were very similar regarding complexity and band position. Cluster analysis generally showed that the vancomycin dosage was the main factor responsible for the separation of the profiles. The presence/absence of a DGGE band and band weighting (band density) analysis revealed that several bacterial community members were affected by the antibiotic treatment (Figure 3).

The calculation of the richness $(S)$ and the Shannon-Wiener index $(H)$ values indicated that especially the soil treated with the higher dosage of vancomycin and/or inoculated with $C$. freundii experienced significant $(P<0.05)$ changes in the overall richness and diversity of the dominant bacteria in comparison to the control soil during the experimental period (Figure 4). The three-way ANOVA analysis showed that the richness value was significantly affected by the bacterial strain $(P<0.001)$, the vancomycin dosage $(P<0.001)$, and the incubation time $(P<0.001 ;$ Table 4$)$. The vancomycin dosage explained most of the variance $(61 \%)$, whereas the effect of the bacterial

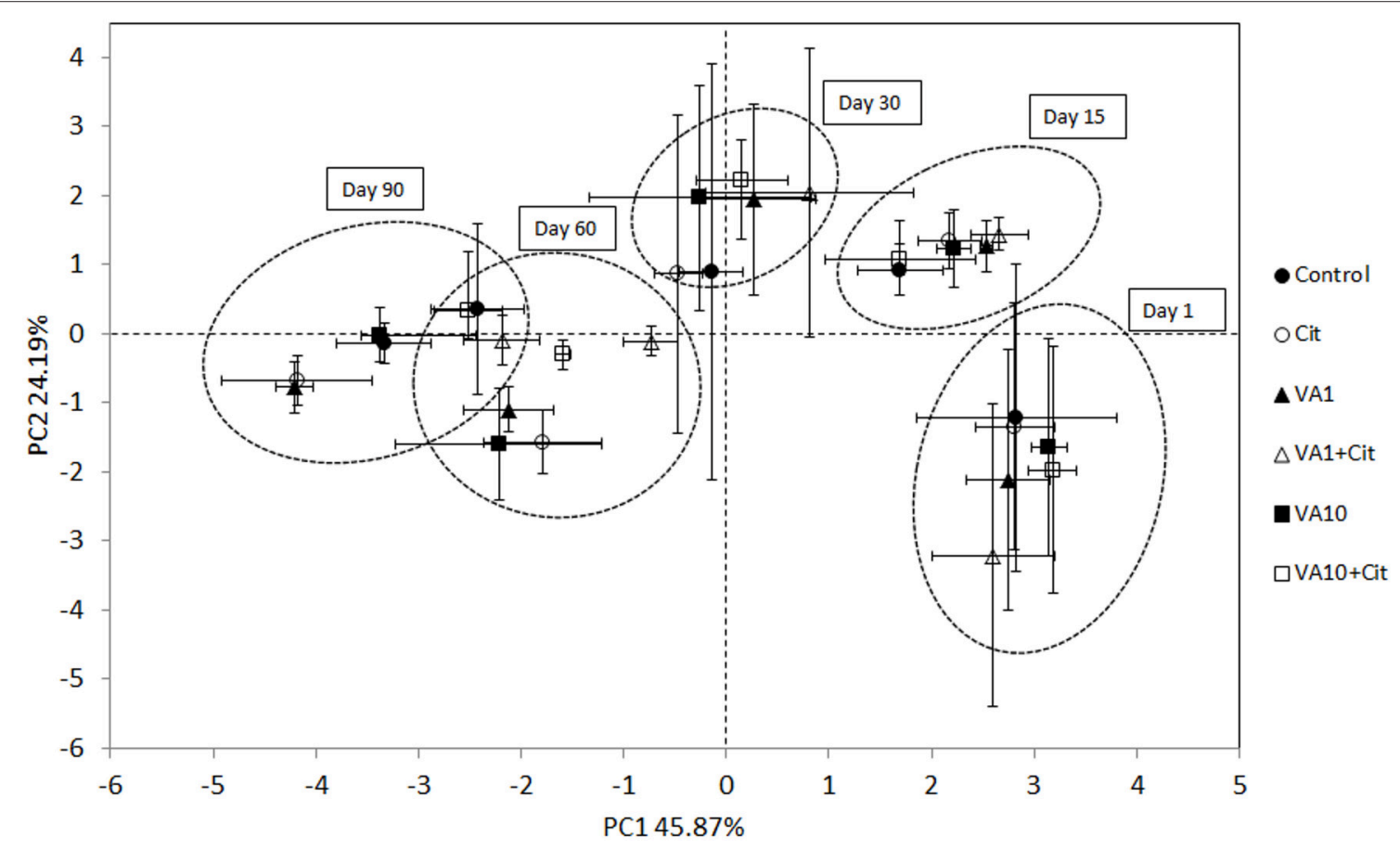

FIGURE 5 | Principal component plots generated from the standardized PLFA biomarker profiles on days 1, 15, 30, 60 and 90. C, control soil; VA1, soil treated with vancomycin $-1 \mathrm{mg} / \mathrm{kg}$ soil; VA10, soil treated with vancomycin-10 mg/kg soil, Cit, soil inoculated with C. freundii; VA1+Cit, soil treated with vancomycin $-1 \mathrm{mg} / \mathrm{kg}$ soil and inoculated with $C$. freundii; VA10+Cit, soil treated with vancomycin $-10 \mathrm{mg} / \mathrm{kg}$ soil and inoculated with $C$. freundii. 
strain accounted for $4 \%$ of the variance and the effect of time explained a further $6 \%$. The interactions between the strain and vancomycin concentration $(\mathrm{S} \times \mathrm{C})$ as well as the concentration and incubation time $(\mathrm{C} \times \mathrm{T})$ were also significant and explained 4 and $6 \%$ of the variance, respectively (Table 4 ). In contrast, the $H$ index was significantly affected only by the vancomycin dosage $(P<0.001)$ and the incubation time $(P<0.001)$, which explained 35 and $22 \%$ of the variance, respectively. The ANOVA also indicated that the incubation time was the only factor that significantly $(P<0.001)$ affected the $E_{H}$ value during the experimental period and explained $30 \%$ of the variance (Table 4).

\section{PLFA Analysis}

The obtained results revealed that vancomycin and/or C. freundii affected the structure of the soil microbial community during the 90-day experiment. The highest value for total PLFA biomass (347.42 nmol PLFA/g soil) was determined on day 1 for soil treated with vancomycin at a higher concentration $(10 \mathrm{mg} / \mathrm{kg}$ soil) and inoculated with C. freundii (VA10+Cit), while the lowest value ( $212.90 \mathrm{nmol} \mathrm{PLFA} / \mathrm{g}$ soil) was found in the control soil (C) on day 60 (Table 5). The three-way ANOVA analysis showed that the total PLFA biomass was significantly affected by the incubation time $(P<0.001)$ and the interactions between three tested factors, i.e., bacterial strain (S), vancomycin concentration $(\mathrm{C})$, and time $(\mathrm{T})(P<0.001)$, which explained 21 and $19 \%$ of the variance, respectively (Table 5 ).

Similar results were obtained for the bacterial PLFA biomass whose value ranged from $82.47 \mathrm{nmol} \mathrm{PLFA} / \mathrm{g}$ soil for the control soil (C) on day 60-132.92 nmol PLFA/g soil for the treated soil (VA10+Cit) on day 1 (Table 5). The bacterial PLFA biomass was shown to be significantly affected by the incubation time $(P<0.001)$ and the interactions between the three tested factors $(\mathrm{S} \times \mathrm{C} \times \mathrm{T} ; P<0.001)$. The interactions between the factors explained $24 \%$ of the variance, whereas the effect of the incubation time accounted for $13 \%$ of the variance (Table 6).
The biomass of the Gram-positive bacteria biomarkers was generally higher than those characteristic for Gram-negative bacteria with maximum values of 73.50 and $43.44 \mathrm{nmol}$ PLFA/g soil, respectively (Table 5). The lowest value for the Grampositive bacteria biomarker biomass ( $40.87 \mathrm{nmol} \mathrm{PLFA} / \mathrm{g}$ soil) was determined for the soil inoculated with C. freundii (Cit) on day 14, while the lowest biomass for Gram-negative biomarkers (29.47 nmol PLFA/g soil) was observed for the control soil (C) on day 60 (Table 5). In both cases, the effect of the time as well as the interactions between the three tested factors $(\mathrm{S} \times \mathrm{C} \times \mathrm{T})$ proved to be the major sources of the variance (10-23\%). However, the effect of the concentration explained a further $5 \%$ of the variance for the biomass of Gram-positive bacteria (Table 6).

The differences in the abundance of the Gram-positive (GP) and Gram-negative (GN) bacteria biomarkers were also reflected by the GP:GN biomarker ratio (Table 5), which was primarily affected by the time factor, which explained most of the variance (60\%). However, this parameter was also significantly $(P<$ $0.05)$ affected by the interaction between the bacterial strain and vancomycin concentration $(\mathrm{S} \times \mathrm{C})$, which explained only $4 \%$ of the variance (Table 6).

The fungal biomass was shown to be significantly affected by the incubation time $(P<0.001)$, which explained most of the variance $(51 \%)$ as well as the concentration of vancomycin $(P<0.05)$; however, this factor explained only $6 \%$ of the variance (Table 6). The ratio of bacteria to fungi (BB:FB) also revealed a time-dependent variance (62\%). The concentration of vancomycin and the interactions between the three tested factors $(\mathrm{S} \times \mathrm{C} \times \mathrm{T})$ significantly affected $(P<0.001$ and $P<0.005)$ the $\mathrm{BB}: \mathrm{FB}$ ratio, which only explained 5 and $9 \%$ of the variance, respectively (Table 6).

The PCA plot obtained for the standardized microbial biomarker profiles revealed a strong time-dependent pattern of variability. Distinct clusters of the samples that had been obtained on different sampling days were scattered along

TABLE 7 | Result of three-way MANOVA for the PC1 and PC2 based on the data for all sampling days.

\begin{tabular}{|c|c|c|c|c|c|c|c|}
\hline PC scores & Source of variation & $d f$ & Sum of squares & Mean squares & Variance explained (\%) & $\boldsymbol{F}$ & $\boldsymbol{P}$ \\
\hline \multirow[t]{7}{*}{ PC1 } & Strain (S) & 1 & 2.79 & 2.79 & $<1$ & 8.9 & $P<0.050$ \\
\hline & Concentration (C) & 2 & 4.15 & 2.08 & $<1$ & 6.7 & $P<0.050$ \\
\hline & Time $(T)$ & 4 & 489.69 & 122.42 & 92 & 395.0 & $P<0.001$ \\
\hline & $\mathrm{S} \times \mathrm{C}$ & 2 & 2.47 & 1.24 & $<1$ & 3.9 & $P<0.050$ \\
\hline & $\mathrm{S} \times \mathrm{T}$ & 4 & 3.00 & 0.75 & $<1$ & 2.4 & $P=0.058$ \\
\hline & $\mathrm{C} \times \mathrm{T}$ & 8 & 4.11 & 0.51 & $<1$ & 1.7 & $P=0.127$ \\
\hline & $\mathrm{S} \times \mathrm{C} \times \mathrm{T}$ & 8 & 5.86 & 0.73 & 1 & 2.4 & $P<0.050$ \\
\hline \multirow[t]{7}{*}{ PC2 } & Strain (S) & 1 & 0.00 & 0.00 & $<1$ & 0.0 & $P=0.989$ \\
\hline & Concentration (C) & 2 & 0.76 & 0.38 & $<1$ & 0.2 & $P=0.797$ \\
\hline & Time $(T)$ & 4 & 152.52 & 38.13 & 54 & 22.7 & $P<0.001$ \\
\hline & $\mathrm{S} \times \mathrm{C}$ & 2 & 2.28 & 1.14 & $<1$ & 0.6 & $P=0.512$ \\
\hline & $S \times T$ & 4 & 1.51 & 0.38 & $<1$ & 0.2 & $P=0.924$ \\
\hline & $\mathrm{C} \times \mathrm{T}$ & 8 & 12.47 & 1.56 & 4 & 0.9 & $P=0.501$ \\
\hline & $\mathrm{S} \times \mathrm{C} \times \mathrm{T}$ & 8 & 9.42 & 1.18 & 3 & 0.7 & $P=0.690$ \\
\hline
\end{tabular}

The effects in bold are significant at $P<0.05$. 
the PC1 axis, which explained $46 \%$ of the total variance, in contrast to the PC2 axis, which explained only 24\% (Figure 5). This observation was confirmed by a three-way MANOVA analysis based on the scores from PC1 and PC2. The time contributed to 92 and $54 \%$ of the total variance observed along PC1 and PC2, respectively. Other factors, such as the concentration of vancomycin, bacterial strain as well as the interactions between three tested factors $(\mathrm{S} \times \mathrm{C} \times \mathrm{T})$
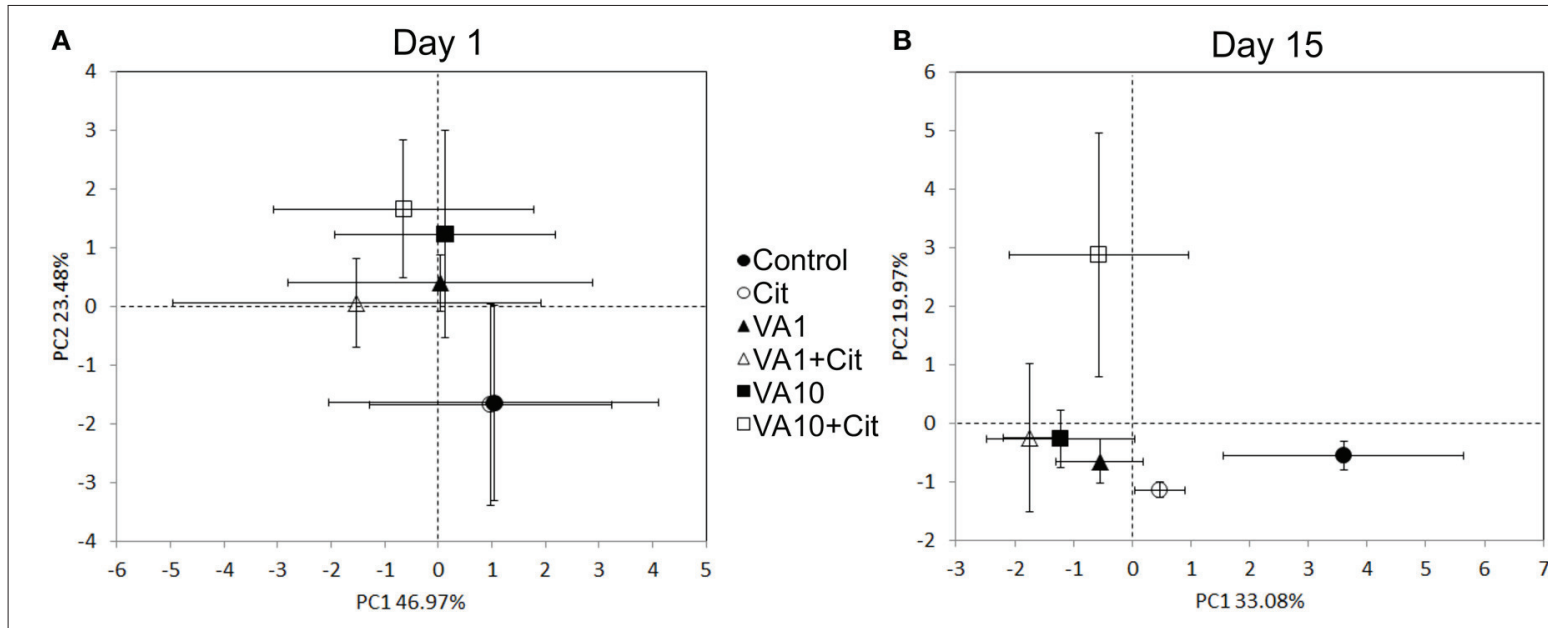

- Control

$\circ$ Cit

$\triangle \mathrm{VA} 1$

$\triangle \mathrm{VA} 1+\mathrm{Cit}$

- VA10

$\square \mathrm{VA} 10+\mathrm{Cit}$
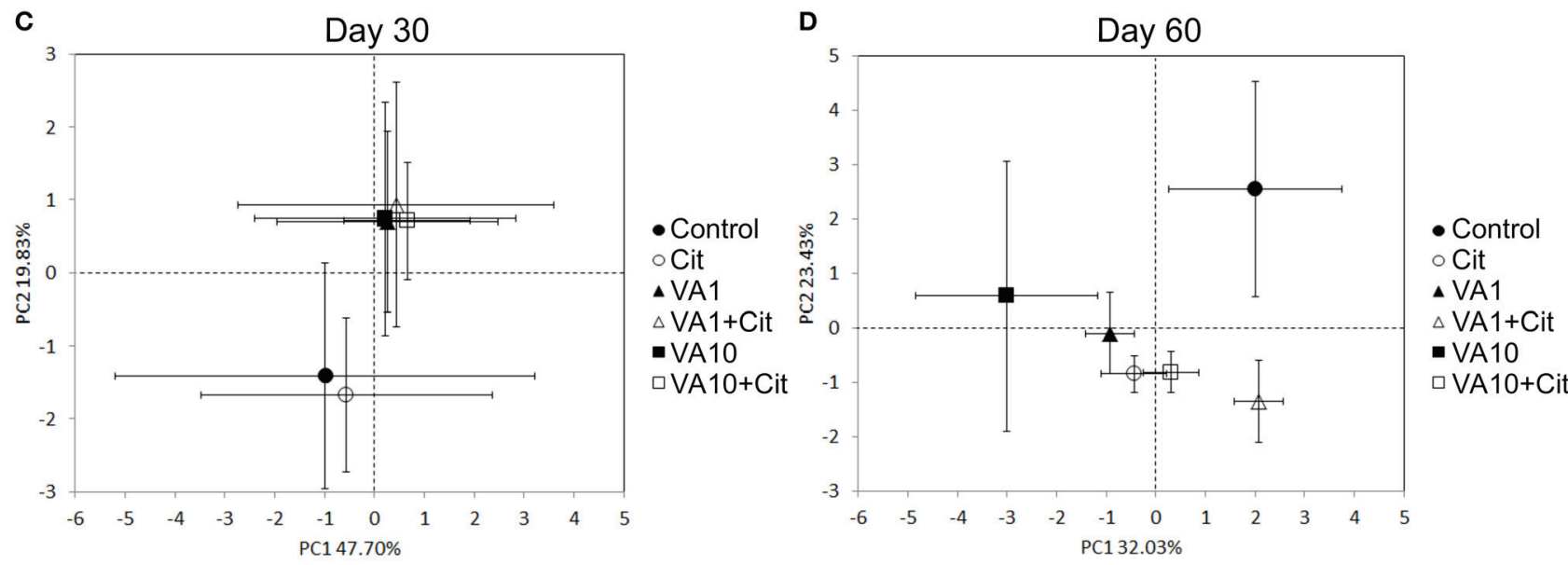

E

Day 90

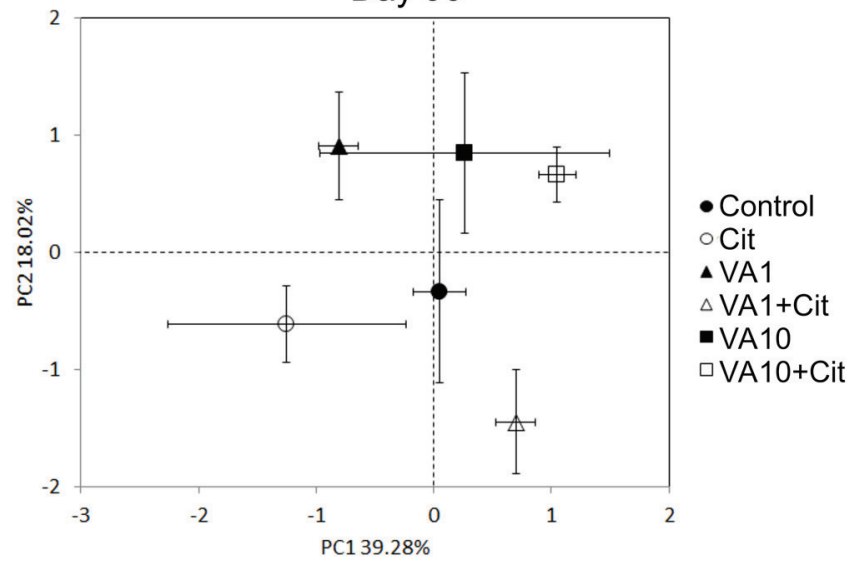

FIGURE 6 | Principal component plots generated from the standardized PLFA biomarker profiles on days 1 (A), 15 (B), 30 (C), 60 (D) and 90 (E). VA1, soil treated with vancomycin $-1 \mathrm{mg} / \mathrm{kg}$ soil; VA10, soil treated with vancomycin-10 mg/kg soil; Cit, soil inoculated with C. freundii; VA1+Cit, soil treated with vancomycin $-1 \mathrm{mg} / \mathrm{kg}$ soil and inoculated with C. freundii; VA10+Cit, soil treated with vancomycin $-10 \mathrm{mg} / \mathrm{kg}$ soil and inoculated with $C$. freundii. 
explained $<1 \%$ of the total variation observed in the PCA scatterplot (Table 7).

The PCA plots performed separately for individual sampling days enabled the impact of factors other than time of the observed variation within the microbial biomarkers to be investigated (Figures 6A-E). In general, a significant impact of the antibiotic concentration was evident up to day 30 of the experiment. This factor contributed to 57,36 , and $49 \%$ of the variance observed along PC2 on days 1, 15, and 30, respectively (Table 8). In addition, the effect of the interaction between the bacterial strain and the vancomycin concentration $(\mathrm{S} \times \mathrm{C}$ ) was found along PC2 on day 15 and it explained 25\% of the variance. In turn, a significant effect $(P<0.001)$ of the vancomycin concentration along PC1 was only observed on day 15 , where this factor explained $51 \%$ of the variance (Figure 6B, Table 8). On days 60 and 90 of the experiment, in addition to the effect of the antibiotic concentration, the effect of the bacterial strain on PLFA profiles was also observed. This effect was mainly associated with PC2 and explained 35 and $23 \%$ of the variance on days 60 and 90 , respectively (Table 8). In turn, the effect of the bacterial strain along PC1 was only observed on day 60 and explained $11 \%$ of the variance. Moreover, the interaction between the strain and the antibiotic concentration $(\mathrm{S} \times \mathrm{C})$ was observed along $\mathrm{PC1}$ and explained 44 and $37 \%$ of the variance on days 60 and 90 , respectively (Table 8 ).

\section{DISCUSSION}

Using an isolation procedure, a bacterial strain identified as C. freundii was screened. Citrobacter species, including

TABLE 8 | Results of two-way MANOVA for the PC1 and PC2 based on the data for each sampling day.

\begin{tabular}{|c|c|c|c|c|c|c|c|c|}
\hline PC scores & Day & Source of variation & $d f$ & Sum of squares & Mean squares & Variance explained (\%) & $\boldsymbol{F}$ & $\boldsymbol{P}$ \\
\hline \multirow[t]{15}{*}{ PC1 } & 1 & Strain (S) & 1 & 2.88 & 2.88 & 3 & 0.4 & $P=0.546$ \\
\hline & & Concentration (C) & 2 & 9.85 & 4.93 & 9 & 0.7 & $P=0.534$ \\
\hline & & $\mathrm{S} \times \mathrm{C}$ & 2 & 1.69 & 0.84 & 2 & 0.1 & $P=0.894$ \\
\hline & 15 & Strain (S) & 1 & 6.76 & 6.76 & 9 & 4.5 & $P=0.056$ \\
\hline & & Concentration (C) & 2 & 37.50 & 18.75 & 51 & 12.4 & $P=0.001$ \\
\hline & & $\mathrm{S} \times \mathrm{C}$ & 2 & 10.73 & 5.36 & 15 & 3.6 & $P=0.061$ \\
\hline & 30 & Strain (S) & 1 & 0.55 & 0.55 & $<1$ & 0.1 & $P=0.802$ \\
\hline & & Concentration (C) & 2 & 5.41 & 2.70 & 5 & 0.3 & $P=0.728$ \\
\hline & & $\mathrm{S} \times \mathrm{C}$ & 2 & 0.07 & 0.03 & $<1$ & 0.0 & $P=0.996$ \\
\hline & 60 & Strain (S) & 1 & 7.52 & 7.52 & 11 & 5.9 & $P<0.050$ \\
\hline & & Concentration (C) & 2 & 16.59 & 8.30 & 23 & 6.6 & $P<0.050$ \\
\hline & & $\mathrm{S} \times \mathrm{C}$ & 2 & 31.49 & 15.74 & 44 & 12.4 & $P=0.001$ \\
\hline & 90 & Strain (S) & 1 & 0.49 & 0.49 & 3 & 1.1 & $P=0.314$ \\
\hline & & Concentration (C) & 2 & 4.77 & 2.38 & 28 & 5.3 & $P<0.050$ \\
\hline & & $\mathrm{S} \times \mathrm{C}$ & 2 & 6.37 & 3.19 & 37 & 7.1 & $P<0.010$ \\
\hline \multirow[t]{15}{*}{ PC2 } & 1 & Strain (S) & 1 & 0.00 & 0.00 & 0.00 & 0.0 & $P=0.980$ \\
\hline & & Concentration (C) & 2 & 29.43 & 14.72 & 57 & 8.0 & $P<0.010$ \\
\hline & & $\mathrm{S} \times \mathrm{C}$ & 2 & 0.45 & 0.23 & 1 & 0.1 & $P=0.885$ \\
\hline & 15 & Strain (S) & 1 & 4.38 & 4.38 & 10 & 4.1 & $P=0.066$ \\
\hline & & Concentration (C) & 2 & 15.73 & 7.86 & 36 & 7.4 & $P<0.010$ \\
\hline & & $\mathrm{S} \times \mathrm{C}$ & 2 & 11.23 & 5.61 & 25 & 5.3 & $P<0.050$ \\
\hline & 30 & Strain (S) & 1 & 0.00 & 0.00 & $<1$ & 0.0 & $P=0.971$ \\
\hline & & Concentration (C) & 2 & 21.46 & 10.73 & 49 & 5.8 & $P<0.050$ \\
\hline & & $\mathrm{S} \times \mathrm{C}$ & 2 & 0.19 & 0.09 & $<1$ & 0.1 & $P=0.950$ \\
\hline & 60 & Strain (S) & 1 & 18.23 & 18.23 & 35 & 10.1 & $P<0.010$ \\
\hline & & Concentration (C) & 2 & 7.54 & 3.77 & 15 & 2.1 & $P=0.167$ \\
\hline & & $\mathrm{S} \times \mathrm{C}$ & 2 & 4.28 & 2.14 & 8 & 1.2 & $P=0.340$ \\
\hline & 90 & Strain (S) & 1 & 3.97 & 3.97 & 23 & 14.4 & $P<0.010$ \\
\hline & & Concentration (C) & 2 & 5.23 & 2.61 & 31 & 9.5 & $P<0.010$ \\
\hline & & $\mathrm{S} \times \mathrm{C}$ & 2 & 4.51 & 2.25 & 27 & 8.2 & $P<0.010$ \\
\hline
\end{tabular}

The effects in bold are significant at $P<0.05$. 
C. freundii, are aerobic gram-negative bacilli. They can inhabit the environment (soils and water), food and the intestinal tracts of animals and humans (Wang et al., 2000). Since it is an opportunistic pathogen, $C$. freundii is often the cause of significant opportunistic infections, meaning that it does not generally cause diseases in healthy human hosts. C. freundii only affects patients with a weak immune system, thus signifying that they need an "opportunity" to infect a person (Whalen et al., 2007). Therefore, Citrobacter species are known to cause a wide variety of nosocomial infections of the respiratory tract, urinary tract and the blood in patients with a suppressed immune system. C. freundii represents $\sim 29 \%$ of all opportunistic infections (Whalen et al., 2007). C. freundii has recently been reported to express resistance to broad-spectrum antibiotics including piperacillin, piperacillin-tazobactam, vancomycin, and cephalosporins (Kim et al., 2003). In our study, the disc diffusion and $E$-test methods showed that the isolated C. freundii was characterized by a resistance not only to vancomycin but also to clindamycin and erythromycin, for which the MICs exceeded $256 \mathrm{mg} / \mathrm{mL}$. The entry of vancomycin-resistant bacteria into soil via the application of manure and sewage sludge produces a potentially significant reservoir of vancomycin-resistance genes (D'Costa et al., 2006; Gullberg et al., 2011). Once antibioticresistant bacteria and their corresponding suites of resistance genes enter the soil, the persistence and fate of these genes depend on the host bacteria that harbor the determinant(s) as well as the partitioning of free genetic material release from cells that may be uptake by new bacterial cells (Salyers and Amábile-Cuevas, 1997; Chee-Sanford et al., 2001).

The introduction of antibiotics and antibiotic-resistant microorganisms into soil leads to changes within the communities of soil microorganisms and the spread of antibiotic-resistance genes and consequently, to a reduction in the effectiveness of antibiotic therapy (D'Costa et al., 2006; Gullberg et al., 2011). It has been demonstrated that antibiotics affect the soil microbial processes, the microbial biomass, the respiration, and the microbial catabolic diversity after the application of these compounds to soil (Conkle and White, 2012; Rosendahl et al., 2012; Cui et al., 2013). For example, a significant decrease in soil activity and respiration as a response to sulfonamides, trimethoprim, and sulfadiazine exposure was reported by Liu et al. (2009) and Kotzerke et al. (2011). Sulfadiazine contamination also resulted in reduced denitrification rates in soil; however, this effect was only observed for a high antibiotic concentration $(100 \mathrm{mg} / \mathrm{kg}$ soil). Schmitt et al. (2005), using the pollution-induced community tolerance (PICT) concept, found that a bacterial community extracted from soil contaminated with sulfachloropyridazine exhibited an increased tolerance to this antibiotic. Moreover, the analysis of community-level physiological profiles (CLPP), which was assessed using Biolog ECP plates, revealed that sulfachloropyridazine caused a statistically important shift in the metabolic activity of soil microbial communities as compared to those in the control soil. A decrease in functional diversity, evenness, average well color development, and substrate utilization of the bacterial populations in soil contaminated with oxytetracycline at concentrations higher than $43 \mu \mathrm{M}$ (to $217 \mu \mathrm{M}$ ) was also revealed by Kong et al. (2006).

The results obtained in this study showed that vancomycin may contribute to qualitative and quantitative changes within indigenous microbial communities. The DGGE profiles of the vancomycin-treated samples differed from the control with the disappearance of some bands following antibiotic application. Changes in the bacterial communities of river sediments exposed to vancomycin at a concentration of $1000 \mu \mathrm{g} / \mathrm{L}$ were also reported by Laverman et al. (2015). Some previously described genotypic analyses of 16S rRNA gene fragment patterns on DGGE also indicated structural shifts within microbial communities through the loss or appearance of bands after various antibiotics were applied to soil (Zielezny et al., 2006; Hammesfahr et al., 2011). Changes in the DGGE banding profiles of $16 \mathrm{~S}$ rRNA genes isolated from sediments contaminated with tetracycline were observed by Roose-Amsaleg et al. (2013). They found that both therapeutic $(10,000 \mu \mathrm{g} / \mathrm{L})$ and environmentally relevant tetracycline concentrations modified the bacteria composition as compared to non-exposed sediments. A modification of the composition of a bacterial community in anaerobic sediments as a response to ciprofloxacin $(20 \mathrm{mg} / \mathrm{mL})$ exposure was reported by Córdova-Kreylos and Scow (2007). Moreover, Fernandes et al. (2015) observed changes in the richness and diversity (assessed using ARISA) of microbial communities in a salt marsh treated with enrofloxacin. In addition, it has been shown that several clinically used antibiotics present in natural environments can select the antibiotics-resistant bacteria (Gullberg et al., 2011; Tang et al., 2015).

The results of our study and other studies may be proof that species sensitive to vancomycin or other antibiotics were killed or their number decreased substantially. The consequence of these changes may be an increase in the number of specific vancomycin-tolerant/resistant bacteria and a decrease in the overall richness $(\mathrm{S})$ and the diversity $(\mathrm{H})$ of the members of bacterial communities. As was revealed by Iweriebor et al. (2015), vancomycin-resistant bacteria have the ability to transfer the vancomycin-resistance determinant to other bacteria and this poses a serious threat to human health. A number of studies have recently shown that the transfer of antibiotic-resistance genes between bacteria occurs frequently in natural ecosystems and hospitals (Onan and LaPara, 2003; Riesenfeld et al., 2004). It has been revealed that the plasmid carrying the Tn1546-like was the main factor in the spread of vancomycin-resistance genes (VanA gene cluster) in enterococcal populations that contributed to an outbreak in hospital (Kawalec et al., 2000).

The changes in the composition of a microbial community based on PLFA analysis observed in this study were also observed by Hund-Rinke et al. (2004) for soils that had been spiked with tetracycline. The authors found a decrease in the amount of specific PLFA biomarkers, which was accompanied by a reduction in the growth of Gram-positive bacteria. The results of a study carried out by Reichel et al. (2013) confirmed the influence of slurry containing sulfadiazine and difloxacin at field-relevant concentrations on the structural diversity of soil microbial communities. They observed a temporal shift and dominance of Gram-negative bacteria in 
soils that had been treated with both antibiotics as indicated by a decreased value of the Gram-positive to Gram-negative ratios. Moreover, they occasionally found a shift toward a higher fungal to bacterial biomass content as reflected by decreased bacteria:fungi PLFA ratios in the antibiotic-treated soils. The reduced bacterial competitiveness, which was often followed by the intensive growth of fungi in antibiotic-polluted soil, was observed by many authors (Hund-Rinke et al., 2004; Hammesfahr et al., 2008; Demoling et al., 2009; Gutiérrez et al., 2010). Reichel et al. (2013) showed that changes in the total PLFA biomass and PLFA patterns obtained from soils treated with sulfadiazine-contaminated manure not only depended on antibiotic application but also on the soil microhabitat (bulk soil, rhizosphere, earthworm burrows, interiors, and surface of aggregates). They stated that the properties of a microhabitat dominated the structure of microbial composition and were reflected by the different responses of communities toward sulfadiazine.

In conclusion, the results of this study indicated that the pollution of soil by vancomycin and/or vancomycinresistant bacteria negatively affected the structure of microbial communities. DGGE analysis confirmed that certain species

\section{REFERENCES}

Arthur, M., Reynolds, P., and Courvalin, P. (1996). Glycopeptide resistance in enterococci. Trends Microbiol. 4, 401-407. doi: 10.1016/0966-842X(96)10 063-9

Aust, M. O., Godlinski, F., Travis, G. R., Hao, X., McAllister, T. A., Leinweber, P., et al. (2008). Distribution of sulfamethazine, chlortetracycline and tylosin in manure and soil of Canadian feedlots after subtherapeutic use in cattle. Environ. Pollut. 156, 1243-1251. doi: 10.1016/j.envpol.2008.03.011

Bååth, E., and Anderson, T. H. (2003). Comparison of soil fungal/bacterial ratios in a $\mathrm{pH}$ gradient using physiological and PLFA-based techniques. Soil Biol. Biochem. 35, 955-963. doi: 10.1016/S0038-0717(03)00154-8

Banerjee, S., and D'Angelo, E. (2013). Livestock antibiotic effects on nitrification, denitrification, and microbial community composition in soils. Open J. Soc. Sci. 3, 203-212. doi: 10.4236/ojss.2013.35024

Bondarczuk, K., Markowicz, A., and Piotrowska-Seget, Z. (2016). The urgent need for risk assessment on the antibiotic resistance spread via sewage sludge land application. Environ. Int. 87, 49-55. doi: 10.1016/j.envint.2015.11.011

Bottoni, P., Caroli, S., and Caracciolo, A. B. (2010). Pharmaceuticals as priority water contaminants. Toxicol. Environ. Chem. 92, 549-565. doi: 10.1080/02772241003614320

Brown, K. D., Kulis, J., Thomson, B., Chapman, T. H., and Mawhinney, D. B. (2006). Occurrence of antibiotics in hospital, residential, and dairy effluent, municipal wastewater, and the Rio Grande in New Mexico. Sci. Total Environ. 366, 772-783. doi: 10.1016/j.scitotenv.2005.10.007

Čermák, L., Kopecky, J., Novotná, J., Omelka, M., Parkhomenko, N., Plháčková, K., et al. (2008). Bacterial communities of two contrasting soils reacted differently to lincomycin treatment. Appl. Soil Ecol. 2, 348-358. doi: 10.1016/j.apsoil.2008.06.001

Chang, S., Sievert, D. M., Hageman, J. C., Boulton, M. L., Tenover, F. C., Downes, F. P., et al. (2003). Infection with vancomycin-resistant Staphylococcus aureus containing the vanA resistance gene. N. Engl. J. Med. 348, 1342-1347. doi: 10.1056/NEJMoa025025

Chee-Sanford, J. C., Aminov, R. I., Krapac, I. J., Garrigues-Jeanjean, N., and Mackie, R. I. (2001). Occurrence and diversity of tetracycline resistance genes in lagoons and groundwater underlying two swine production facilities. Appl. Environ. Microbiol. 67, 1494-1502. doi: 10.1128/AEM.67.4.1494-150 2.2001 within the bacterial community were sensitive to vancomycin as was evidenced by the absence of some DGGE bands and decrease in the values of biodiversity indices. However, it can be assumed that the number of species characterized by a higher tolerance/resistance to this antibiotic will increase over time. The observed changes in the structure of soil bacteria may also result in a lower rate of important soil processes, which can lead to the disturbance of the ecological balance of the soil ecosystem as well as in the spread of vancomycin-resistance genes.

\section{AUTHOR CONTRIBUTIONS}

Conceived and designed experiments: MC. Contributed reagents and materials, performed experiments: $\mathrm{MC}, \mathrm{SB}$, and $\mathrm{KO}$. Analyzed results: MC, SB, TW, and ZP. Wrote the paper: MC, $\mathrm{SB}$, and $\mathrm{ZP}$

\section{ACKNOWLEDGMENTS}

This study was performed within the framework of the projects (KNW-1-100/N/4/0 and KNW-2-017/D/5/N) founded by the Medical University of Silesia.

Conkle, J. L., and White, J. R. (2012). An initial screening of antibiotic effects on microbial respiration in wetland soils. J. Environ. Sci. Health A 47, 1381-1390. doi: 10.1080/10934529.2012.672315

Córdova-Kreylos, A. L., and Scow, K. M. (2007). Effects of ciprofloxacin on salt marsh sediment microbial communities. ISME J. 1, 585-595. doi: 10.1038/ismej.2007.71

Courvalin, P. (2006). Vancomycin resistance in Gram-Positive cocci. Clin. Infect. Dis. 42, S25-S34. doi: 10.1086/491711

Cui, H., Wang, S.-P., Jia, S.-G., Zhang, N., and Zhou, Z.-Q. (2013). Influence of ciprofloxacin on the microbial catabolic diversity in soil. J. Environ. Sci. Health B 48, 869-877. doi: 10.1080/03601234.2013.796826

Cycoń, M., Piotrowska-Seget, Z., and Kozdrój, J. (2010). Microbial characteristics of sandy soils exposed to diazinon under laboratory conditions. World J. Microbiol. Biotechnol. 26, 409-418. doi: 10.1007/s11274-009-0 183-3

Cycoń, M., Zmijowska, A., and Piotrowska-Seget, Z. (2014). Enhancement of deltamethrin degradation by soil bioaugmentation with two different strains of Serratia marcescens. Int. J. Environ. Sci. Technol. 11, 1305-1316. doi: 10.1007/s13762-013-0322-0

D'Costa, V. M., McGrann, K. M., Hughes, D. W., and Wright, G. D. (2006). Sampling the antibiotic resistome. Science 311, 374-377. doi: $10.1126 /$ science. 1120800

Demoling, L. A., Bååth, E., Greve, G., Wouterse, M., and Schmitt, H. (2009). Effects of sulfamethoxazole on soil microbial communities after adding substrate. Soil Biol. Biochem. 41, 840-848. doi: 10.1016/j.soilbio.2009.02.001

Fatta-Kassinos, D., Kalavrouziotis, I. K., Koukoulakis, P. H., and Vazquez, M. I. (2011). The risk associated with wastewater reuse and xenobiotics in the agroecological environment. Sci. Total Environ. 409, 3555-3563. doi: 10.1016/j.scitotenv.2010.03.036

Fernandes, J. P., Almeida, C. M. R., Basto, M. C. P., and Mucha, A. P. (2015). Response of a salt marsh microbial community to antibiotic contamination. Sci. Total Environ. 532, 301-308. doi: 10.1016/j.scitotenv.2015.06.029

Figueroa-Diva, R. A., Vasudevan, D., and MacKay, A. A. (2010). Trends in soil sorption coefficients within common antimicrobial families. Chemosphere 79 , 786-793. doi: 10.1016/j.chemosphere.2010.03.017

Förster, M., Laabs, V., Lamshöft, M., Groeneweg, J., Zühlke, S. Z., Spiteller, M., et al. (2009). Sequestration of manure-applied sulfadizine residues in soils. Environ. Sci. Technol. 43, 1824-1830. doi: 10.1021/es8026538 
Frostegård, A., and Bååth, E. (1996). The use of phospholipid analysis to estimate bacterial and fungal biomass in soil. Biol. Fertil. Soils 22, 59-65. doi: 10.1007/BF00384433

Frostegård, A., Bååth, E., and Tunlid, A. (1993). Shifts in the structure of soil microbial communities in limed forests as revealed by phospholipid fatty acid analysis. Soil Biol. Biochem. 25, 723-730. doi: 10.1016/0038-0717(93)90113-P

Gartiser, S., Urich, E., Alexy, R., and Kümmerer, K. (2007). Anaerobic inhibition and biodegradation of antibiotics in ISO test schemes. Chemosphere 66, 1839-1848. doi: 10.1016/j.chemosphere.2006.08.040

Gullberg, E., Albrecht, L., M., Karlsson, C., Sandegren, L., and Andersson, D. I. (2014). Selection of a multidrug resistance plasmid by sublethal levels of antibiotics and heavy metals. MBio 5, e01918-e01914. doi: 10.1128/mBio.01918-14

Gullberg, E., Cao, S., Berg, O. G., Ilbäck, C., Sandegren, L., Hughes, D., et al. (2011). Selection of resistant bacteria at very low antibiotic concentrations. PLoS Pathog. 7:e1002158. doi: 10.1371/journal.ppat.1002158

Gupta, A., Biyani, M., and Khaira, A. (2011). Vancomycin nephrotoxicity: myths and facts. Neth. J. Med. 69, 379-383.

Gutiérrez, I., Watanabe, N., Harter, T., Glaser, B., and Radke, M. (2010). Effect of sulfonamide antibiotics on microbial diversity and activity in a Californian Mollic Haploxeralf. J. Soil Sediments 10, 537-544. doi: 10.1007/s11368-0090168-8

Hammesfahr, U., Bierl, R., and Thiele-Bruhn, S. (2011). Combined effects of the antibiotic sulfadiazine and liquid manure on the soil microbialcommunity structure and functions. J. Plant Nutr. Soil Sci. 174, 614-623. doi: 10.1002/jpln.201000322

Hammesfahr, U., Heuer, H., Manzke, B., Smalla, K., and Thiele-Bruhn, S. (2008). Impact of the antibiotic sulfadiazine and pig manure on the microbial community structure in agricultural soils. Soil Biol. Biochem. 40, 1583-1591. doi: 10.1016/j.soilbio.2008.01.010

Hektoen, H., Berge, J. A., Hormazabal, V., and Yndestad, M. (1995). Persistence of antibacterial agents in marine sediments. Aquaculture 133, 175-184. doi: 10.1016/0044-8486(94)00310-K

$\mathrm{Hu}, \mathrm{X}$., Zhou, Q., and Luo, Y. (2010). Occurrence and source analysis of typical veterinary antibiotics in manure, soil, vegetables and groundwater from organic vegetable bases, northern China. Environ. Pollut. 158, 2992-2998. doi: 10.1016/j.envpol.2010.05.023

Hund-Rinke, K., Simon, M., and Lukow, T. (2004). Effects of tetracycline on the soil microflora: function, diversity, resistance. J. Soils Sediments 4, 11-16. doi: 10.1007/BF02990823

Ingerslev, F., and Halling-Sorensen, B. (2001). Biodegradability of metronidazole, olaquindox, and tylosin and formation of tylosin degradation products in aerobic soil-manure slurries. Ecotoxicol. Environ. Saf. 48, 311-320. doi: 10.1006/eesa.2000.2026

Iweriebor, B. C., Gaqavu, S., Obi, L. C., Nwodo, U. U., and Okoh, A. I. (2015). Antibiotic susceptibilities of Enterococcus species isolated from hospital and domestic wastewater effluents in Alice, eastern Cape Province of South Africa. Int. J. Environ. Res. Public Health 12, 4231-4246. doi: 10.3390/ijerph1204 04231

Karci, A., and Balcioglu, I. A. (2009). Investigation of the tetracycline, sulfonamide, and fluoroquinolone antimicrobial compounds in animal manure and agricultural soils in Turkey. Sci. Total Environ. 407, 4652-4664. doi: 10.1016/j.scitotenv.2009.04.047

Kawalec, M., Gniadkowski, M., and Hryniewicz, W. (2000). Outbreak of vancomycin-resistant Enterococci in a hospital in Gdańsk, Poland, due to horizontal transfer of different Tn1546-like transposon variants and clonal spread of several strains. J. Clin. Microbiol. 38, 3317-3322.

Kim, P. W., Harris, A. D., Roghmann, M.-C., Morris, J. G. Jr., Strinivasan, A., and Perencevich, E. N. (2003). Epidemiological risk factors for isolation of ceftriaxone-resistant versus - susceptible Citrobacter freundii in hospitalized patients. Antimicrob. Agents Chemother. 47, 2882-2887. doi: 10.1128/AAC.47.9.2882-2887.2003

Kong, W. D., Zhu, Y. G., Fu, B. J., Marschner, P., and He, J. Z. (2006). The veterinary antibiotic oxytetracycline and $\mathrm{Cu}$ influence functional diversity of the soil microbial community. Environ. Pollut. 143, 129-137. doi: 10.1016/j.envpol.2005.11.003

Kotzerke, A., Hammesfahr, U., Kleineidam, K., Lamshöft, M., Thiele-Bruhn, S., Schloter, M., et al. (2011). Influence of difloxacin-contaminated manure on microbial community structure and function in soils. Biol. Fertil. Soils 47, 177-186. doi: 10.1007/s00374-010-0517-1

Kümmerer, K. (2003). Significance of antibiotics in the environment. J. Antimicrob. Chemother. 52, 5-7. doi: 10.1093/jac/dkg293

Kümmerer, K. (2009). Antibiotics in the aquatic environment - A review - part I. Chemosphere 75, 417-434. doi: 10.1016/j.chemosphere.2008.11.086

Kwon, J. W. (2011). Mobility of veterinary drugs in soil with application of manure compost. Bull. Environ. Contam. Toxicol. 87, 40-44. doi: 10.1007/s00128-0110297-9

Lane, D. J. (1991). “16S/23S rRNA sequencing," in Nucleic Acid Techniques in Bacterial Systematics, eds E. Stackebrandt and M. Goodfellow (Chichester: John Wiley and Sons), 177-203.

Larsson, D. G. J., de Pedro, C., and Paxeus, N. (2007). Effluent from drug manufactures contains extremely high levels of pharmaceuticals. J. Hazard Mater. 148, 751-755. doi: 10.1016/j.jhazmat.2007.07.008

Laverman, A. M., Cazier, T., Yan, C., Roose-Amsaleg, C., Petit, F., Garnier, J., et al. (2015). Exposure to vancomycin causes a shift in the microbial community structure without affecting nitrate reduction rates in river sediments. Environ. Sci. Pollut. Res. Int. 22, 13702-13709. doi: 10.1007/s11356-015-4159-6

Li, B., and Zhang, T. (2010). Biodegradation and adsorption of antibiotics in the activated sludge process. Environ. Sci. Technol. 44, 3468-3473. doi: $10.1021 /$ es $903490 \mathrm{~h}$

Li, B., and Zhang, T. (2011). Mass flows and removal of antibiotics in two municipal wastewater treatment plants. Chemosphere 83, 1284-1289. doi: 10.1016/j.chemosphere.2011.03.002

Liu, F., Ying, G. G., Tao, R., Zhao, J. L., Yang, J. F., and Zha, L. F. (2009). Effects of six selected antibiotics on plant growth and soil microbial and enzymatic activities. Environ. Pollut. 157, 1636-1642. doi: 10.1016/j.envpol.2008. 12.021

Łuczkiewicz, A., Jankowska, K., Fudala-Książek, S., and Olańczuk-Neyman, K. (2010). Antimicrobial resistance of fecal indicators in municipal wastewater treatment plant. Water Res. 44, 5089-5097. doi: 10.1016/j.watres.2010. 08.007

Morris, D., Galvin, S., Boyle, F., Hickey, P., Mulligan, M., and Cormican, M. (2012). Enterococcus faecium of the vanA genotype in rural drinking water, effluent, and the aqueous environment. Appl. Environ. Microbiol. 78, 596-598. doi: 10.1128/AEM.06636-11

Muyzer, G., de Wall, E. C., and Witterlinden, A. G. (1993). Profiling of complex microbial populations by denaturing gradient gel electrophoresis analysis of polymerase chain reaction-amplified genes coding for 16S rRNA. Appl. Environ. Microbiol. 59, 695-700.

Nagulapally, S. R., Ahmad, A., Henry, A., Marchin, G. L., Zurek, L., and Bhandari, A. (2009). Occurrence of ciprofloxacin-, trimethoprim-sulfamethoxazole-, and vancomycin-resistant bacteria in a municipal wastewater treatment plant. Water Environ. Res. 81, 82-90. doi: 10.2175/106143008X304596

Onan, L. J., and LaPara, T. M. (2003). Tylosin-resistant bacteria cultivated from agricultural soil. FEMS Microbiol. Lett. 220, 15-20. doi: 10.1016/S03781097(03)00045-4

Passerat, J., Tamtam, F., Le Bot, B., Eurin, J., Chevreuil, M., and Servais, P. (2010). Antimicrobials and faecal bacteria resistant to antimicrobials in the rivers of the Seine River watershed: impacts of hospital effluents. Eur. J. Water Qual. 41, 1-13. doi: 10.1051/water/2010004

Reichel, R., Rosendahl, I., Peeters, E. T. H. M., Focks, A., Groeneweg, K. J. I., and Bierl, R. (2013). Effects of slurry from sulfadiazine- (SDZ) and difloxacin - (DIF) medicated pigs on the structural diversity of microorganisms in bulk and rhizosphere soil. Soil Biol. Biochem. 62, 82-91. doi: 10.1016/j.soilbio.2013.03.007

Riesenfeld, C. S., Goodman, R. M., and Handelsman, J. (2004). Uncultured soil bacteria are a reservoir of new antibiotic resistance genes. Environ. Microbiol. 6, 981-989. doi: 10.1111/j.1462-2920.2004.00664.x

Roose-Amsaleg, C., Yan, C., Hoang, A. M., and Laverman, A. M. (2013). Chronic exposure of river sediments to environmentally relevant levels of tetracycline affects bacterial communities but not denitrification rates. Ecotoxicology 22, 1467-1478. doi: 10.1007/s10646-013-1133-2

Rosendahl, I., Siemens, J., Kindler, R., Groeneweg, J., Zimmermann, J., Czerwinski, S., et al. (2012). Persistence of the fluoroquinolone antibiotic difloxacin in soil and lacking effects on nitrogen turnover. J. Environ. Qual. 41, 1275-1283. doi: $10.2134 /$ jeq2011.0459 
Salyers, A. A., and Amábile-Cuevas, C. F. (1997). Why are antibiotic resistance genes so resistant to elimination? Antimicrob. Agents Chemother. 41, 2321-2325.

Schmitt, H., Haapakangas, H., and van Beelen, P. (2005). Effects of antibiotics on soil microorganisms: time and nutrients influence pollutioninduced community tolerance. Soil Biol. Biochem. 37, 1882-1892. doi: 10.1016/j.soilbio.2005.02.022

Su, J., Wei, B., Ou-Yang, W. Y., Huang, F., Zhao, Y., Xu, H., et al. (2015). Antibiotic resistome and its association with bacterial communities during sewage sludge composting. Environ. Sci. Technol. 49, 7356-7363. doi: 10.1021/acs.est.5b 01012

Sujatha, S., and Praharaj, I. (2012). Glycopeptide resistance in gram-positive cocci: a review. Interdiscip. Perspect. Infect. Dis. 2012:781679. doi: $10.1155 / 2012 / 781679$

Sukul, P., Lamshöft, M., Zühlke, S., and Spiteller, M. (2008). Sorption and desorption of sulfadiazine in soil and soil-manure systems. Chemosphere 73, 1344-1350. doi: 10.1016/j.chemosphere.2008.06.066

Tamtam, F., van Oort, F., Le Bot, B., Dinh, T., Mompelat, S., Chevreuil, M., et al. (2011). Assessing the fate of antibiotic contaminants in metal contaminated soils four years after cessation of long-term waste water irrigation. Sci. Total Environ. 409, 540-547. doi: 10.1016/j.scitotenv.2010. 10.033

Tang, X., Lou, C., Wang, S., Lu, Y., Liu, M., Hashmi, M. Z., et al. (2015). Effects of long-term manure applications on the occurrence of antibiotics and antibiotic resistance genes (ARGs) in paddy soils: evidence from four field experiments in south of China. Soil Biol. Biochem. 90, 179-187. doi: 10.1016/j.soilbio.2015.07.027

Wang, J. T., Chang, S. C., Chen, Y. C., and Luh, K. T. (2000). Comparison of antimicrobial susceptibility of Citrobacter freundii isolates in two different time periods. J. Microbiol. Immunol. Infect. 33, 258-262.
Weerasinghe, C. A., and Towner, D. (1997). Aerobic biodegradation of virginiamycin in soil. Environ. Toxicol. Chem. 16, 1873-1876. doi: $10.1002 /$ etc. 5620160916

Whalen, J. G., Mully, T. W., and Enlgish, J. C. (2007). Spontaneous Citrobacter freundii infection in an immunocompetent patient. Arch. Dermatol. 143, 124-125. doi: 10.1001/archderm.143.1.124

Xiong, W., Sun, Y., Ding, X., W, M., and Zeng, Z. (2015). Selective pressure of antibiotics on ARGs and bacterial communities in manurepolluted fresh water-sediment microcosms. Front. Microbiol. 6:194. doi: 10.3389/fmicb.2015.00194

Zielezny, Y., Groeneweg, J., Vereecken, H., and Tappe, W. (2006). Impact of sulfadiazine and chlorotetracycline on soil bacterial community structure and respiratory activity. Soil Biol. Biochem. 38, 2372-2380. doi: 10.1016/j.soilbio.2006.01.031

Zuccato, E., Castiglioni, S., Bagnati, R., Melis, M., and Fanelli, R. (2010). Source, occurrence and fate of antibiotics in the Italian aquatic environment. J. Hazard Mater. 179, 1042-1048. doi: 10.1016/j.jhazmat.2010.03.110

Conflict of Interest Statement: The authors declare that the research was conducted in the absence of any commercial or financial relationships that could be construed as a potential conflict of interest.

Copyright (c) 2016 Cycoń, Borymski, Orlewska, Wasik and Piotrowska-Seget. This is an open-access article distributed under the terms of the Creative Commons Attribution License (CC BY). The use, distribution or reproduction in other forums is permitted, provided the original author(s) or licensor are credited and that the original publication in this journal is cited, in accordance with accepted academic practice. No use, distribution or reproduction is permitted which does not comply with these terms. 